\title{
INTERPRETATION OF FUNDAMENTAL RIGHTS IN SLOVENIA
}

\author{
BENJAMIN FLANDER
}

\section{A Brief Summary of the Content}

This chapter introduces an analysis of the interpretation of fundamental rights in the practice of the Slovenian Constitutional Court and the European Court of Human Rights. A brief overview of the status and powers of the Constitutional Court is followed by a record of the common features of the constitutional adjudication and style of reasoning in fundamental rights cases. Then the application of fundamental rights will be analysed and the practice of interpreting them by the Slovenian Constitutional Court will be explored. In this main segment of our research we analysed 30 important cases of the last 10 years in which the Constitutional Court brought a final decision, and in which it made a substantive references to the judgements of either the European Court of Human Rights (ECtHR) or the European Court of Justice (ECJ). Among the selected cases, 19 decisions were issued in the constitutional complaint procedure and 11 decisions concern the review of the constitutionality of laws and other general acts, however in some decisions, these two types of constitutional judicial decision-making are both involved. The selected decisions refer to important aspects of the implementation of fundamental rights in the areas of criminal law and criminal procedure, civil law, administrative law, anti-discrimination law, family law, asylum law, European Union law and other areas of law. For different reasons, the majority of these decisions have been of outstanding relevance in Slovenia.

Benjamin Flander (2021) Interpretation of Fundamental Rights in Slovenia. In: Zoltán J. Tóth (ed.) Constitutional Reasoning and Constitutional Interpretation, pp. 99-179. Budapest-Miskolc, Ferenc Mádl Institute of Comparative Law-Central European Academic Publishing. 
The selected cases will be analysed according to the common methodology of the monograph, aimed at comparing the interpretation of fundamental rights in the case law of the constitutional courts of the countries of the Eastern Central European region, the ECtHR and the ECJ. Carefully scrutinizing them, we discovered that the Constitutional Court - while using different methods of legal interpretation addressed a wide range of constitutional provisions and rights. The Constitutional Court's interpretation of the constitutional provisions on fundamental rights contained in the selected decisions has had precedent effects on the legal order of the Republic of Slovenia. In substantive terms, in these cases, the Constitutional Court has taken a position on important aspects of the implementation of fundamental rights and determined their scope and limits. Furthermore, it has addressed the substantive meaning of important parts of the so-called constitutional material core (i.e., of principles of democracy, the rule of law and the separation of powers, of human dignity, personal liberty and privacy in a democratic state, etc.) and took decisions that have led to amendments in different areas of the Slovenian legal order.

Following the analyses of the features of constitutional adjudication and reasoning in Slovenia, we will then proceed with exploring the judicial practice of the ECtHR and, to a much lesser extent, the ECJ, the two very important international courts. 28 cases of the ECtHR and 2 cases of the ECJ referenced by the Slovenian Constitutional Court will be scrutinised. The selected decisions of both international courts were considered on the merits in the decisions of Constitutional Court which were included in our study. Our survey in the section concerning ECtHR aims primarily at providing a record of the common features of the interpretation by the Court of fundamental rights enshrined in the European Convention on Human Rights (hereinafter Convention). We will try to determine main differences in the decisionmaking and reasoning style of the Slovenian Constitutional Court and the ECtHR, while the comparison with the adjudication practice of the ECJ and interpretation of the rights contained in the Charter of Fundamental Rights of the European Union is of lesser importance for this study.

\section{An overview of the Status and Powers of the Slovenian Constitutional Court}

\subsection{The Status}

The Republic of Slovenia is a young country, which gained independence from the communist Yugoslavia on June 25, 1991, adopted new democratic Constitution on December 23, 1991, and joined the European Union on May 1, 2004. Coming into force six months after the declaration of independence, the new Constitution of the Republic of Slovenia (hereinafter the Constitution) defines Slovenia as a democratic 
state based on principles of popular sovereignty, separation of powers and the rule of law. ${ }^{1}$ It introduces an extensive catalogue of human rights and fundamental freedoms and regulates the status and powers of the most important state and independent bodies including the Constitutional Court, which was introduced in Slovenia by the 1963 Constitution. With the new Constitution, it has acquired new important competences and a stronger position in the judicial branch of power. ${ }^{2}$

As the highest body of judicial power for the protection of constitutionality, legality and human rights, the Constitutional Court is regulated in the Constitution in an independent chapter (Articles 160-167), separate from the chapter on state regulation as well as from the chapter on the judiciary. The Constitution determines the powers of the Constitutional Court and the position of its judges. The Constitutional Court's powers are determined in more detail in the Constitutional Court Act (hereinafter the CCA), adopted in 1994, which also regulates the financing of the Constitutional Court and the position of the President, the Secretary General, judges and advisers, and, in its largest section, the proceedings before the Constitutional Court (see below). ${ }^{3}$ In order to independently regulate its organization and to determine in more detail the rules governing its proceedings, in 2007 the Constitutional Court adopted its Rules of Procedure. ${ }^{4}$

The Constitutional Court is an autonomous and independent state authority in relation to other state bodies and public authorities. Such position of the Constitutional Court is necessary due to its role as a guardian of constitutional order and enables an independent and impartial decision-making in protecting constitutionality as well as human rights of individuals and the constitutional rights of legal entities in relation to any authority. ${ }^{5}$ Also important for its independent and autonomous status is that the Court determines independently its internal organization and mode of operation, and retains the budgetary autonomy and independence. Funds for the work of the Constitutional Court are determined as a part of the state budget by the National Assembly (e.g. the Parliament) upon the proposal of the Court itself. While the Court decides on the use of the funds autonomously, the supervision of the use of

1 The Constitution of the Republic of Slovenia (Ustava Republike Slovenije [Constitution]), Official Gazette of the Republic of Slovenia No. 33/91, 42/97, 66/00, 24/03, 69/04, 68/06, 47/13, 75/16, 92/21.

2 Constitution, Art. 160-167; Kaučič and Grad, 2011, pp. 333-350; see also The Constitutional Court of the Republic of Slovenia - An Overview of the Work for 2019, p. 9.

3 The Constitutional Court Act (Zakon o ustavnem sodišču [CCA]), Official Gazette of the Republic of Slovenia No. 64/07 - official consolidated text, 109/12, 23/20, 92/21.

4 The Rules of Procedure (Poslovnik Ustavnega sodišča Republike Slovenije [Rules of Procedure]), Official Gazette of the Republic of Slovenia, No. 86/07, 54/10, 56/11, 70/17 and 35/20. Adopted at the administrative session held on 17 September 2007 and amended at the administrative session held on 8 July 2010 and 4 July 2011, the Rules of Procedure entail detailed provisions on the representation, organization, operation and the public nature of the work of the Constitutional Court, as well as on the position of the judges, consideration and deciding.

5 The Constitutional Court of the Republic of Slovenia - An Overview of the Work for 2019, pp. 11-14. 
these funds is performed by the Court of Audit. ${ }^{6}$ The work of the Constitutional Court is public, according to the criteria set out by the CCA.

The Constitutional Court consists of nine judges who are elected on the proposal of the President of the Republic by secret ballot by a majority vote of all members of the National Assembly. They are elected for a term of nine years and may not be re-elected. Any Slovenian citizen who is a legal expert and has reached at least 40 years of age may be elected a Constitutional Court judge. ${ }^{7}$ The manner of electing constitutional judges is regulated in more detail by the provisions of Articles 11 to 14 of the CCA. The President of the Republic publishes a call for candidates in the Official Gazette. Proposed candidatures must include a statement of reasons and the written consent of the candidates that they accept their candidature. While the President of the Republic proposes candidates for vacant positions from among the proposed candidates, he may additionally propose other candidates. If the President of the Republic proposes more candidates than there are vacant positions on the Constitutional Court, the order of candidates on the ballot is determined by lot. If none of the candidates receives the required majority or if an insufficient number of judges are elected, those candidates who received the highest number of votes are voted on again. If, even after a repeated election, an insufficient number of candidates are elected to the Constitutional Court, the President of the Republic conducts a new call for candidates in the Official Gazette and a new election is held on the basis of new candidatures. ${ }^{8}$ Upon the proposal of the President of the Republic, the Parliament dismisses a Constitutional Court judge before the expiry of his or her term of office if the judge him or herself so requests, if the judge is punished by imprisonment for a criminal offence, or due to permanent loss of capacity to perform the office. ${ }^{9}$

The office of a Constitutional Court judge is incompatible with any office or work in public or private entities, with membership in management and supervisory bodies and the pursuit of occupation or activity, except for the position of higher education teacher or researcher. An elected Constitutional Court judge takes office after taking the oath of office and enjoys the same immunity as deputies of the National Assembly. The Constitutional Court has a President who is elected by secret ballot by the judges for a term of three years. ${ }^{10}$

\subsection{The Powers}

The Slovenian Constitutional Court exercises extensive jurisdiction intended to ensure effective protection of constitutionality and legality, as well as to prevent violations of fundamental rights. ${ }^{11}$ While the majority of its powers are determined

6 CCA, Art. 6 and 8; see also Mavčič, 2000, pp. 82-93 and 98-100.

7 Constitution, Art. 162 and 163.

8 CCA, Art. 11-14.

9 Constitution, Art. 164; CCA, art. 19; see also Mavčič, 2000, pp. 124-125.

10 Constitution, Art. 163, 165, 166 and 167; CCA, Art. 9, 14, 16 and 17; Rules of Procedure, Art. 5-9.

11 Krivic, 2000, p. 47. 
by the Constitution, they are regulated in more detail in the CCA. The competences of the Constitutional Court include deciding on (a) the constitutionality of laws and of the constitutionality and legality of other general acts, (b) the constitutionality of the international treaties prior to their ratification, (c) constitutional complaints regarding violations of fundamental rights, (d) disputes regarding the admissibility of a legislative referendum, (e) jurisdictional disputes, (f) the impeachment of the President of the Republic, the President of the Government, and individual ministers, (g) the unconstitutionality of the acts and activities of political parties, (h) disputes on the confirmation of the election of deputes of the National Assembly, and (i) the constitutionality of the dissolution of a municipal council or the dismissal of a major. ${ }^{12}$ The Constitutional Court also decides on several other matters vested in it by the CCA and other laws. ${ }^{13}$

In terms of their significance and share of the caseload, the most important powers of the Slovenian Constitutional Court are the review of the constitutionality of laws and of the constitutionality and legality of other general acts (e.g. sub-statutory acts) and the power to decide on constitutional complaints regarding violations of fundamental rights.

\subsubsection{The Proceedings for the Review of the Constitutionality of Laws}

Article 161 of the Constitution stipulates that if the Constitutional Court establishes that a law is unconstitutional, it abrogates such law in whole or in part. Such abrogation takes effect immediately or within a period of time determined by the Constitutional Court. The Constitutional Court annuls ab initio (ex tunc) or abrogates (ex nunc) government's regulations or other sub-statutory general acts that are unconstitutional or contrary to laws. The Constitutional Court may, up until a final decision, also suspend in whole or in part the implementation of an act whose constitutionality or legality is being reviewed. According to the CCA, the proceedings for the review of the constitutionality of laws and the constitutionality and legality of other general acts adopted by state and other public authorities (e.g. norm control proceedings) can be initiated by the submission of a written request by the National Assembly ${ }^{14}$, one third of the deputies of the National Assembly ${ }^{15}$, the National Council, the Government, the Ombudsman (if he deems that a law or executive regulation

12 Constitution, Art. 160; CCA, Art. 21.

13 For example, the Referendum and Popular Initiative Act (Zakon o referendumu in ljudski iniciativi [ZRLI], Official Gazette of the Republic of Slovenia No. 26/07 - official consolidated text, 52/20) stipulates in Article 5 č that if the National Assembly decides to not call the referendum, the proposers of the request may, within eight days of the decision of the National Assembly, request that such decision be reviewed by the Constitutional Court. If the Constitutional Court establishes that the decision of the National Assembly is unfounded, it shall abrogate it.

14 The National Assembly shall adopt its decision on the submission of a written request by a majority of votes cast by those deputies present.

15 In Slovenia, normally, the parliamentary opposition holds at least one third of the seats in the National Assembly. Accordingly, it often uses the possibility to initiate norm control proceedings. 
interferes with fundamental rights), the Information Commissioner, the Bank of Slovenia, the Court of Audit and the State Prosecutor General (provided that a question of constitutionality or legality arises in connection with a case or procedure they are conducting), local councils (provided that a law or any other general act interferes with the constitutional position or constitutional rights of a local community), and representative trade unions (provided that the rights of workers are threatened). ${ }^{16}$ The Protection Against Discrimination Act, adopted in 2016, provided for such a competence also for the Advocate of the Principle of Equality. ${ }^{17}$ Additionally, when a court of general jurisdiction deems an act or its individual provisions, which it should apply to be unconstitutional, it stays the proceedings and by a request initiates proceedings for the review of their constitutionality. ${ }^{18}$ The above listed applicants, however, may not submit a request to initiate the procedure for the review of the constitutionality or legality of general acts if these acts were adopted by them.

The proceedings for the review of the constitutionality of laws and sub-statutory general acts can also be initiated by a Constitutional Court order on the acceptance of a petition to initiate a review procedure which may be lodged by anyone - be it natural or legal person - who demonstrates legal interest. Pursuant to the CCA, the legal interest is deemed to be demonstrated if a law, executive regulation or other general act whose review has been requested by the petitioner directly interferes with his/her rights, legal interests or legal position. A petition must contain, inter alia, information from which it is evident that the challenged law or other general act directly interferes with the petitioner's rights, legal interests, or legal position, and proof of the petitioner's legal status in instances in which the applicant is not a natural person. The petitioner must also submit the relevant documents to which he refers to support his/her legal interest. ${ }^{19}$ In norm control proceedings, each participant bears his own costs, unless the Constitutional Court decides otherwise.

The CCA distinguishes between the procedure for examining a petition and the preparatory procedure. A petition is first examined by the Constitutional Court judge determined by the work schedule (e.g. judge rapporteur), who collects information and obtains clarifications necessary for the Constitutional Court to decide whether to

16 CCA, Art. 22 and 23a.

17 The Protection Against Discrimination Act (Zakon o varstvu pred diskriminacijo [ZVarD]), Official Gazette of the Republic of Slovenia No. 33/16 - unofficial consolidated text, 33/16 and 21/18 ZNOrg. Article 38 of the ZVarD stipulates that if the Advocate of the Principle of Equality assesses that a law or other general act is discriminatory he or she may, by a request, initiate the proceedings for the review of constitutionality or legality of such an act.

18 The CCA also stipulates that if by a request the Supreme Court initiates proceedings for the review of the constitutionality of an act or part thereof, a court which should apply such act in deciding may stay proceedings until the final decision of the Constitutional Court without having to initiate proceedings for the review of the constitutionality of such act by a separate request. Furthermore, if the Supreme Court deems a law or part thereof which it should apply to be unconstitutional, it stays proceedings in all cases in which it should apply such law or part thereof in deciding on legal remedies and by a request initiates proceedings for the review of its constitutionality (see Art. 23).

19 CCA, Art. 22-24b. 
initiate a procedure. The Constitutional Court may reject a petition unless all formal and procedural requirements regarding legal interest are met or dismiss a petition if it is manifestly unfounded or if it cannot be expected that an important legal question will be resolved. At the centre of the preparatory procedure, which follows the procedure for examining a petition, is the communication between the parties (i.e., the adversarial principle). The Constitutional Court sends the request or petition to the authority which issued the general act (e.g. to the opposing party), and determines an appropriate period of time for a response or for a supplementary response if a response has already been submitted in the procedure for examining the petition. ${ }^{20}$

When the preparatory procedure is completed, the Constitutional Court considers a case at a closed session or a public hearing where a majority of all Constitutional Court judges must be present. Until its final decision, the Constitutional Court may suspend in whole or in part the implementation of a law, executive regulation or other general act adopted by a public authority, if harmful consequences that are difficult to remedy could result from the implementation of those acts. If the Constitutional Court suspends the implementation of a general act, it may at the same time decide in what manner the decision is to be implemented. An order by which the implementation of a general act is suspended must include a statement of reasons. The suspension takes effect the day following the publication of the order in the Official Gazette of the Republic of Slovenia, and in the event of a public announcement of the order, the day of its announcement. ${ }^{21}$

The Constitutional Court decides on the merits by a decision by a majority vote of all judges. ${ }^{22}$

It may in whole or in part abrogate a law which is not in conformity with the Constitution. When deciding on the constitutionality and legality of government's regulations or other sub-statutory general acts adopted by public authorities, however, the Constitutional Court may either abrogate or annul them. It may annul unconstitutional or unlawful sub-statutory general acts when it determines that it is necessary to remedy harmful consequences arising from such unconstitutionality or unlawfulness. Such an annulment has retroactive effect (ex tunc) and if harmful consequences occurred as a result of a regular court decision or any other individual act adopted on the basis of the annulled general act, entitled persons have the right to request that the authority which decided in the first instance annul such individual act. If such consequences cannot be remedied, however, the entitled person may claim compensation in a regular court of law. ${ }^{23}$

In other instances, when the Constitutional Court abrogates general acts that are unconstitutional or unlawful ${ }^{24}$, the abrogation takes effect on the day following

20 CCA, Art. 27 and 28.

21 CCA, Art. 39. See also Mavčič, 2000, pp. 211-216.

22 Other issues are decided by an order adopted by a majority vote of the judges present.

23 CCA, Art. $46 \S 1$. See also Mavčič, 2000, p. 262-270.

24 The Constitutional Court may also extend the review to a review of the conformity of the challenged acts with ratified international treaties and with the general principles of international law. 
the publication of the Constitutional Court's decision on the abrogation, or upon the expiry of a period of time determined by the Constitutional Court (ex nunc). ${ }^{25}$ A different situation arises when laws or other general acts are found unconstitutional by the Constitutional Court because they do not regulate a certain issue which they should regulate or they regulate it in a manner which does not enable annulment or abrogation. In such cases a so-called declaratory decision is adopted by the Constitutional Court. Furthermore, the Constitutional Court also adopts a declaratory decision when deciding on the constitutionality of general acts that have ceased to be in force. ${ }^{26}$ In these cases, the legislature or the authority which issued the unconstitutional or unlawful general act must remedy the established unconstitutionality or unlawfulness within a period of time determined by the Constitutional Court. ${ }^{27}$

During proceedings before the Constitutional Court, a situation may occur that a law or other general act ceased to be in force as a whole or in the challenged part or was amended. In such circumstances, the Constitutional Court decides on its constitutionality or legality if an applicant or petitioner demonstrates that the consequences of the unconstitutionality or unlawfulness of such law or other general act were not remedied. ${ }^{28}$ In its case law however, the Constitutional Court determined an additional condition for taking the challenged law into consideration if it ceased to be in force during the proceedings. It will take such a law or other general act into consideration and decide on its constitutionality if the initiative for a norm control relates to particularly important constitutional issues of a systemic nature and if a precedent decision is to be expected. ${ }^{29}$

In the Slovenian consttutioal system the Constitutional Court cannot initiate any procedure ex officio. However, there is a narrow and conditioned exception as Article 30 of the CCA stipulates that in deciding on the constitutionality and legality of general acts, the Constitutional Court is not bound by the proposal of a request or petition. The Constitutional Court may also review the constitutionality and legality of other provisions of the same or other laws or sub-statutory general acts for which a review of constitutionality or legality has not been proposed, if such provisions are mutually related or if such is necessary to resolve the case at hand. ${ }^{30}$

25 CCA, Art. 43-45; see also Mavčič, 2000, p. 238-260. For a comprehensive study on the different types of the Slovenian Constitutional Court's decisions and their consequences, see Krivic, 2000, pp. 47-211.

26 CCA, Art. 47 and $48 \S 1$. By adopting a so-called declaratory decision, the Constitutional Court does not annul or abrogate an unconstitutional act. Instead, it determines a time limit by which the legislature or other authority that issued an act must remedy the established unconstitutionality or illegality. See Mavčič, 2000, pp. 270-273. For a comprehensive study on the declaratory decisions see Nerad, 2007.

27 CCA, Art. $48 \S 2$.

28 CCA, Art. 47.

29 See, for example, U-I-50/21, dated 15 April 2021.

30 CCA, Art. 30. See also Krivic, 2000, p. 131. 


\subsubsection{The Constitutional Complaint}

Another important power of the Slovenian Constitutional Court is the power to decide on constitutional complaints regarding violations of fundamental rights. A constitutional complaint in the Slovenian legal order is generally considered to be neither a regular nor an extraordinary legal remedy, but a special legal remedy for the protection of human rights and fundamental freedoms. ${ }^{31} \mathrm{~A}$ constitutional complaint may be lodged to claim a violation of rights and freedoms determined by the Constitution as well as those recognised by applicable international treaties. Under the conditions determined by the CCA, any natural or legal person may file constitutional complaint if he/she/it deems that his/her/its fundamental rights have been violated by an individual act of state authorities, local community authorities, or other bearers of public authority. A constitutional complaint may also be lodged by the ombudsman in connection with an individual case which he/she is considering with the consent of the person whose fundamental rights he/she is protecting. A constitutional complaint may be lodged only when all regular and extraordinary legal remedies have been exhausted, and no later than within 60 days from the day of service of the individual act against which a constitutional complaint is possible. ${ }^{32}$

A constitutional complaint is not admissible if the alleged violation of fundamental rights did not have serious consequences for the complainant. In connection with this, the CCA stipulates that there is no violation of fundamental rights which would have serious consequences for the complainant, when (a) an individual act is issued in small-claim disputes, (b) if only a decision on the costs of proceedings is challenged by the constitutional complaint, (c) in trespass to property disputes and (d) in minor offence cases. Notwithstanding this legal presumption, the Constitutional Court may, in specially substantiated cases, also decide on constitutional complaints against such individual acts if the case addresses an important constitutional issue that exceeds the significance of the concrete case. ${ }^{33}$

Furthermore, the Art. 55b, § 1 of the CCA determines the instances in which in the procedure for examining a constitutional complaint a panel of three judges ${ }^{34}$ sitting in a closed session shall reject a constitutional complain. Among these are the following ones:

31 Ude, 1995, p. 515 cited in Fišer, 2000, pp. 278-279.

32 CCA, Art. 50-52. The Constitutional Court may exceptionally decide on a constitutional complaint before the exhaustion of extraordinary legal remedies, if the alleged violation is obvious, if the regular legal remedies are exhausted and if the execution of an individual legal act would have irreparable consequences for the complainant. In specially justified cases, as an exception, a constitutional complaint may also be lodged on the expiry of the prescribed time limit (see Art.51 $\S 2$ and Mavčič, 2000, pp. 326-330.

33 CCA, Art. 55a.

34 The Constitutional Court has three panels for the examination of constitutional complaints: the panel for constitutional complaints in the field of criminal law matters, in the field of civil law matters and in the field of administrative law matters (se below). 
- if the complainant does not have a legal interest for a decision on the constitutional complaint;

- if all legal remedies have not been exhausted;

- if the challenged act is not an individual act by which a state authority, local community authority, or any other bearer of public authority decided on the rights, obligations or legal entitlements of the complainant;

- if a constitutional complaint was lodged by a person not entitled to do so, if it was not lodged in time and in other instances determined by the CCA.

However, the constitutional complaint is accepted for consideration by a panel if a violation of fundamental rights could have serious consequences for the complainant or if it concerns an important constitutional question which exceeds the importance of the concrete case. ${ }^{35}$

Regarding the decision-making on the acceptance or rejection of the constitutional complaint for consideration, the relevant provisions on the procedure for examining a constitutional complaint are very unique. According to the Rules of Procedure, the panel of three judges decides whether the conditions for the acceptance and consideration of a constitutional complaint determined by the Article 55b of the CCA are fulfilled. If the members of a panel do not agree whether the reasons referred to in the CCA exist, the constitutional complaint is submitted to the Constitutional Court judges who are not members of the panel in order to decide thereon. The constitutional complaint may be either rejected (i.e., if any five Constitutional Court judges decide in favour of rejection in writing within 15 days) or accepted for consideration (i.e., if any three Constitutional Court judges decide in favour of acceptance in writing within 15 days). ${ }^{36}$

Once a constitutional complaint is accepted, as a general rule it is considered by the Constitutional Court at a closed session, or a public hearing may be held (see below). The panel of three judges or the Constitutional Court at the plenary sitting may suspend the implementation of the challenged individual act at a closed session if harmful consequences that are difficult to remedy could result from the implementation thereof. Following consideration on the merits of a case, the Constitutional Court dismisses as unfounded the constitutional complaint or it grants the complaint and annuls or abrogates, in whole or in part, the challenged individual act and the matter is returned to the authority competent to decide thereon. ${ }^{37}$ However, if it is necessary to remedy the consequences which have already arisen, or if the nature of the constitutional right so requires, the Constitutional Court can decide on the constitutional right by itself. This decision must be implemented by the authority competent to implement the individual act which the Constitutional Court abrogated or annulled. Las but not least, if the Constitutional Court finds that a repealed 
individual act is based on an unconstitutional general act, it may annul or abrogate such an act in accordance with the provisions of the CCA on the proceedings regarding the review of constitutionality and legality of laws and other general acts. ${ }^{38}$

\subsection{Conclusion}

The Slovenian Constitutional Court decides by decisions and orders. Participants in proceedings before the Constitutional Court have the right to inspect the case file at all times during the proceedings, while other persons may do so if the President of the Constitutional Court allows them to do so. As a general rule, the cases are deliberated and decisions are taken in closed sessions. In some cases, however, a public hearing is held (see below, subsection 2.1.1). ${ }^{39}$ The Constitutional Court ensures that the public is informed of its work in particular by publishing its decisions and orders in the Official Gazette of the Republic of Slovenia, on its website, and in a collection of decisions and orders of the Constitutional Court, which is periodically published in a book form. In cases that are of more interest to the public, the Court issues a special press release in order to publicize its decisions. The work of the Court is presented to the public also through the publication of annual reports on its work and decisions.

Since the establishment of the new Constitutional Court of an independent and sovereign Slovenia, its influence on the personal, family, economic, cultural, religious, and political life of the Slovenian society has been of extreme importance. From a substantive perspective, decisions on the merits, by which the Constitutional Court adopts precedential standpoints regarding the standards of protection of constitutional values, especially fundamental rights, are of particular importance for the development of law in general and constitutional law in particular. This is due to the fact that the actual content of the constitutional norms/rights is, to a large extent, the result of the Court's interpretation of individual provisions and the Constitution as a whole. The decisions of the Constitutional Court breathe substance and meaning into the Constitution and its provisions on fundamental rights, thus making them a living and effective legal tool that can directly influence people's lives and wellbeing. As a result of the deployment of different types of interpretative arguments and methods, the case law of the Constitutional Court relating to fundamental rights extends to all legal fields and touches upon various dimensions of individual existence and of society as a whole. ${ }^{40}$

38 CCA, Art. 59 \& 2.

39 In deciding on an individual case, the Constitutional Court may disqualify a Constitutional Court judge by applying, mutatis mutandis, the reasons for disqualification of judges in a regular court proceedings. Pursuant to Art. 31 of the CCA, the following are not reasons for disqualification of a judge of the Constitutional Curt: (a) participation in legislative procedures or in the adoption of other challenged regulations or general acts issued for the exercise of public authority prior to being elected a Constitutional Court judge, and (b) the expression of an expert opinion on a legal issue which might be significant for the proceedings.

40 The Constitutional Court of the Republic of Slovenia - An Overview of the Work for 2019, pp. 9-10. 


\section{The Interpretation of Fundamental Rights in the Case Law of the Constitutional Court}

In the following subsections, a picture will be drawn of the characteristics of the constitutional decision-making process and adjudication, the style of reasoning of the Constitutional Court and the frequency of methods and arguments used by it when interpreting constitutional provisions on fundamental rights. The insight into the interpretative practices detected in the 30 selected decisions of the Slovenian Constitutional Court will be followed by an analysis of the selected judgements of the ECtHR (accompanied with a few judgments of the ECJ) referred to in the Constitutional Court's case law. In the concluding section of the chapter, a comparison between the Constitutional Court and the ECtHR/ECJ will be made in terms of characteristics of their adjudicating and reasoning style and of the methods of legal interpretation used by them.

\subsection{The characteristics of the Constitutional Court's decision-making and style of reasoning}

In the first place we will shed some more light on the normative framework of considering and adjudicating cases by the Constitutional Court and take a closer look at the way decisions are taken and at the characteristics and style of the constitutional reasoning in cases involving interpretation of constitutional provisions on fundamental rights. More particularly, we will try to clarify how the constitutional decision-making is conducted and what fundamental rights and constitutional tests and standards are employed in the course of constitutional reasoning and adjudicating in each main type of cases.

\subsubsection{The normative framework ${ }^{41}$ of considering cases and decision-making}

As a general rule, the Constitutional Court considers cases in accordance with the order of their receipt, however, it may decide to consider certain types of cases as priority cases, while certain cases shall be considered by the Court as such ex lege. ${ }^{42}$

41 As indicated in the introduction to this chapter, the general normative framework of considering cases and decision-making by the Constitutional Court is determined by the CCA and the Rules of Procedure. Also relevant for the operation of cases and decision-making of the Constitutional Court are standards formulated by the Constitutional Court itself in its case law.

42 The Constitutional Court may decide to consider the following types of cases as priority cases: (a) cases which the court must consider and decide rapidly in accordance with the regulations that apply on the basis of the CCA; (b) cases in which a court has adjourned proceedings and required the review of the constitutionality of a law; (c) cases for which a law determines a time limit within which the Constitutional Court must consider and decide a case and (d) jurisdictional disputes (Rules of Procedure, Art. 46). 
If a participant in proceedings motions for priority consideration, the Constitutional Court decides thereon if so proposed by the judge rapporteur or another Constitutional Court judge.

The assignment of cases to Constitutionla Court judges and schedule of sessions are determined by the Constitutional Court by means of a work schedule adopted at an administrative session. Cases are as a general rule assigned to Constitutional Court judges according to the alphabetical order of their last names. Constitutional complaint cases are assigned to Constitutional Court judges, with consideration of which panel they have been assigned to, according to the alphabetical order of the last names of the members of the panel. ${ }^{43}$ The method of assigning cases to the Constitutional Court judges, the division of work between the panels of the Constitutional Court and their composition as well as the shedule of sessions are also published in the Official Gazette and on the website of the Constitutional Court. ${ }^{44}$

The Constitutional Court decides on a case which is the subject of proceedings at a session on the basis of the written or oral report of the judge-rapporteur ${ }^{45}$ or on the basis of a submitted draft decision (or order). If the judge rapporteur assesses that a case is more demanding or if such is required by any Constitutional Court judge at a session, a written report of the case is drawn up. The report comprises whatever is necessary for the Constitutional Court to decide, i.e., a review of whether the procedural requirements have been fulfilled, a presentation of previous relevant constitutional case law, a comparative survey of relevant constitutional reviews or reviews by international courts, other comparative-law information, a presentation of foreign and domestic legal theory, selected preparatory materials for the Constitution and the challenged regulations, and arguments in favour and against possible solutions. ${ }^{46}$ The judge-rapporteur may obtain necessary clarifications also from other participants in proceedings and from state authorities, local community authorities, and bearers of public authority.

In the stage of preparation of the material for the session, the advisers to the Constitutional Court have an important role as they prepare a draft decision (or

43 As explined in the section on the Constitutional Court's powers, the Court has three three-member panels for the examination of constitutional complaints. The division of work among the panels and the composition thereof is regulated by the Constitutional Court according to the work schedule.

44 Rules of Procedure, Art. 10-12.

45 While the President of the Constitutional Court decides when the case is ready for voting, the judge-rapporteur is the key person for the text of the draft decision. Since the latter is often coordinated in a session, it can be amended only with his consent. Sometimes judges submit their motions (e.g. their proposals of the decision for consideration at a session) in writing before the session. If these are such that they cannot be accepted by the judge-rapporteur, then, as a rule, he proposes that a new judge-rapporteur be appointed to prepare a new draft decision. In some cases, a preliminary vote is taken on the whole decision or only on parts of the decision, in order to verify the support, the draft prepared by the judge-rapporteur enjoys. New rounds of discussion then take place in order to see if consensus can be reached. Where this is not possible, the case is adjourned, with the judge-rapporteur and the adviser seeking to prepare a draft acceptable to the majority of judges.

46 Rules of Procedure, Art. 47. 
order) and report for the judge-rapporteur. The judge-rapporteur may either sign and send the prepared material to the secretary-general for admission to the session, or reject it and give the adviser instructions on how to amend or supplement the material. Sometimes this process of consultation between the judge-rapporteur and the adviser takes place earlier in informal or formal communication, but not necessarily in all cases. In formal communication, it takes place when the adviser first prepares a report only for the judge-rapporteur, to which he responds. Once the judge-rapporteur and the adviser have reconciled the text, the latter prepares the material for the session which should be signed by the judge-rapporteur before the submission. In the absence of such communication, when the judge-rapporteur merely signs the material, the adviser has a great influence on the draft decision or order. However, although in some cases the author of the text of a draft decision (or order) may be the adviser, the text of the decision or part of the decision is often prepared by the judgerapporteur alone or together with other judges or advisers. In practice, on the one hand, judges often give advisers a chance to speak and give their opinion significant weight. On the other hand, there is no doubt that the responsibility and therefore also a final word is always with the judge him/herself.

The Constitutional Court considers a case either at a closed session or a public hearing where a majority of all Constitutional Court judges must be present. Closed sessions are called in accordance with the work schedule of the Constitutional Court. In addition to the President and judges of the Constitutional Court, the Secretary General, the advisors of the Constitutional Court who have been assigned a case and other advisors who are selected by the President or the judge rapporteur are present at closed sessions. At the beginning of the consideration of each item on the agenda, the President allows the judge rapporteur to speak, and then other Constitutional Court judges, moving clockwise, such that the judge sitting to the left of the judge rapporteur follows first. The President speaks after all other judges have stated their opinion on the matter. The President may then allow the Secretary General and, upon the proposal of the judge rapporteur, the Advisor present at particular items of the agenda to speak. After the discussion of an item on the agenda is concluded the President submits the proposed decision to a vote. While the vote may be either preliminary or final, a final vote may be carried out only on a draft decision (or a draft order) which includes the operative provisions and its full reasoning, except in cases when the Constitutional Court pronounces its decision orally, immediately after the conclusion of a public hearing (see below). However, if the conditions for reaching a decision are not fulfilled, the Constitutional Court may decide by a majority vote of the judges present to adjourn the decision on such to a later session. ${ }^{47}$

47 Rules of Procedure, Art. 55-63. If the judge-rapporteur does not propose otherwise, proposals for the temporary suspension of the implementation of laws and other general acts are considered by the Constitutional Court in a correspondence session, in such a manner that the judge rapporteur submits a report and a draft decision to the other Constitutional Court judges. If none of the Constitutional Court judges declares his opposition to the draft decision within eight days or within a time limit determined by an order of the Constitutional Court, such decision is adopted. The 
A public hearing may be called on the initiative of the President of the Constitutional Court or upon the motion of the participants in proceedings. A proposal that a public hearing be called or a proposal on the partial or complete exclusion of the public from a hearing may also be contained in a report prepared by the judgerapporteur (see supra). Upon the proposal of three judges, however, a public hearing is obligatory. The deliberation and voting on the decision of a case that is considered at a public hearing is carried out at a closed session and only those Constitutional Court judges who were present at the public hearing cast votes. ${ }^{48}$

The Constitutional Court's decisions (and orders) shall contain the statement of the legal basis for deciding, the operative provisions, the statement of reasons, and the statement of the composition of the Constitutional Court which reached the decision. The operative provisions contain the decision on the commencement of proceedings, the decision on the review of the general or individual act that was the subject of the review, the decision on the manner of the implementation of the decision or the order, and the decision on the costs of proceedings, if such were claimed by a participant in proceedings. The most interesting and important obligatory component of a decision (or an order) is, in the context of this chapter, the statement of reasons (e.g. the reasoning). It contains a summary of the allegations of the participants in proceedings and the reasons for the decision of the Constitutional Court. A decision (or an order) also includes a statement on the results of the vote and the names of the Constitutional Court judges who voted against the decision, the names of the Constitutional Court judges who submitted separate opinions, and the names of the Constitutional Court judges who were disqualified from deciding.

\subsubsection{The characteristics of decision-making and style of reasoning}

The characteristics of decision-making of the Constitutional Court are largely dependent on the type of a case. As explained in the introductory section on the Constitutional Court, norm control proceedings can be initiated by the submission of a written request by the applicants determined by the CCA and other laws or by a petition to initiate a review procedure which may be lodged by anyone who demonstrates legal interest. If the latter is the case, the legal interest is considered to be demonstrated if a law or other general act to be reviewed directly interferes with a petitioner's rights, legal interests or legal position. In this type of cases, prior to adjudicating on the merits of a case, the Constitutional Court examines in the preparatory procedure the petition, determining whether the petitioner has demonstrated

Constitutional Court may decide that it will also decide other types of cases in this manner (Rules of Procedure, Art. 56). Decisions and orders which contain reasoning are always considered in a regular session (e.g. not in a correspondence session) for a more detailed discussion of the content and deliberation.

48 Rules of Procedure, Art. 51-53 and 55. 
legal interest. Pursuant to the CCA, the Constitutional Court dismisses a petition if it is manifestly unfounded or if it cannot be expected that an important legal question will be resolved. It decides on the acceptance or dismissal of a petition by a majority vote of judges present. The order adopted by the Constitutional Court to dismiss a petition must include a statement of reasons. ${ }^{49}$

In its judicial practice, the Slovenian Constitutional Court determined more precisely the content of the provision of the CCA on the legal interest and tightened the conditions to be met by a petitioner. It has taken a position that as a general rule legal interest in filing a petition is demonstrated if the petitioner is involved in a concrete legal dispute in which he/she has exhausted all regular and extraordinary legal remedies and if a petition is filed together with a constitutional complaint against an individual legal act. Although this is not a general rule and it does not apply to all petitions in general, according to the criteria set up in the case law of the Constitutional Court a petition must be such as to raise particularly important precedential constitutional questions of a systemic nature. The stricter standard applies only in specific circumstances in specific cases. ${ }^{50}$

A good illustration of the application of strict criteria for examining a petition and determining whether the petitioner has demonstrated legal interest can be found in the Constitutional Court's decision number U-I-83/20. In this case, the Constitutional Court reviewed the constitutionality of two ordinances adopted by the Government in order to contain and manage the risk of the COVID-19 epidemic. The question at issue was whether the prohibition of movement outside the municipality of one's permanent or temporary residence determined by the challenged executive ordinances was consistent with the first paragraph of Article 32 of the Constitution, which guarantees freedom of movement to everyone. ${ }^{51}$ An important circumstance in this case was that the petitioner has not been involved in a concrete legal dispute (i.e., he was not convicted of a misdemeanour for violating the government's ordinances) and has not filled, together with his petition for the review of the two ordinances, a constitutional complaint against an individual legal act. In its order which was issued in the procedure for examining the petition and preceded the final/substantive decision, the Constitutional Court referred to its previous decisions in similar matters and held that it is not possible to require the petitioner to violate the allegedly unconstitutional or illegal provisions of the ordinances and initiate misdemeanour proceedings in order to substantiate the legal interest for filling a petition. The judges also assessed that in the present case, the petition for the review of the constitutionality and legality of government's general acts raises a particularly important precedential constitutional question of a systemic nature on which the Constitutional Court had not yet had the opportunity to take a position and which could also arise in connection with possible future acts of the same nature. On the

49 CCA, Art. $26 \S 2$ and 3.

50 See Mavčič, 2000, pp. 172-189.

51 U-I-83/20, dated 27 August 2020. 
basis of these arguments, the Constitutional Court ruled that the petitioner succeeded to demonstrate the legal interest. ${ }^{52}$

In norm control proceedings, a petitioner is entitled to propose to the Constitutional Court to issue a temporary injunction on and suspend the implementation of the challenged general acts until the final decision. Such proposals are based on the first paragraph of Article 39 of the CCA, which stipulates that the Constitutional Court may suspend the execution of a general act in whole or in part until the final decision, if its implementation could result in harmful consequences that are difficult to remedy. For cases involving the temporary injunction proposals, the Constitutional Court developed in its case law a special argumentative formula. When employing it, the Court weighs between the harmful consequences that would be caused by the implementation of possibly unconstitutional provisions of the challenged general act and the harmful consequences that would arise if the challenged provisions, which could possibly be recognized in the Court's final decision as compliant with the Constitution, were not temporarily implemented. In cases where the Constitutional Court finds that both the further effect of the challenged provisions and their temporary suspension could lead to comparable harmful consequences that are difficult to remedy, it rejects the motion for temporary suspension. Notably, in in the procedure for examining the petition in the aforementioned case number U-I$83 / 20$, the petitioner's motion to suspend the provision prohibiting the movement outside the municipality of one's permanent or temporary residence has been rejected. In the then present circumstances of the COVID-19 pandemic, the majority of the Constitutional Court's judges considered consequences that would arise for the public health and preservation of people's lives, if the challenged provisions were not implemented until the Constitutional Court's final decision, more harmful than the consequences that would be caused by the implementation of possibly unconstitutional provisions of the government's decrees for the implementation of the right to free movement. ${ }^{53}$

In the reasoning of its final decisions in norm control proceedings, the Constitutional Court first provides a summary of the allegations of petitioners/applicants and of the opposite participant (e.g. the authority which issued the challenged general act) ${ }^{54}$ and then gives reasons for the decision on the (un)constitutionality of the challenged provisions of laws or other general acts. In most cases which concern fundamental rights, the Court carries out the review of constitutionality on the basis of the test of legitimacy and the strict test of proportionality. While the former entails an assessment of whether the legislature or other law-giving entity pursued a constitutionally admissible objective, the latter comprises an assessment of whether the

52 U-I-83/20-10, dated 27 August 2020.

53 See U-I-83/20-10. The temporary injunction proposal by the petitioner was rejected by six votes to three.

54 In cases where - not the sub-statutory general acts but - the law has been challenged by the petitioner, beside the National Assembly also the government may give its opinion. 
interference was appropriate, necessary, and proportionate in the narrower sense. In its case law, the Constitutional Court determined in general terms under what conditions an interference (e.g. a measure limiting a fundamental right) is appropriate, necessary, and proportionate. Firstly, the assessment of the appropriateness of a measure includes the assessment of whether the objective pursued can be achieved at all by the intervention or whether the measure alone or in combination with other measures can contribute to the achievement of this objective. According to the Constitutional Court, a measure is inappropriate if its effects on the pursued goal could be assessed as negligible or only accidental at the time of its adoption. Secondly, an interference with a human right or fundamental freedom is necessary, according to the Constitutional Court, if the pursued goal cannot be achieved without interference or with a milder but equally effective measure. Finally, an interference with a fundamental right is proportionate in the narrower sense if the severity of that interference is proportionate to the value of the objective pursued or to the expected benefits that will result from the interference. ${ }^{55}$

When taking a final decision in the COVID-19 case about prohibition of movement outside the municipality of one's residence, the Constitutional Court assessed that the Government pursued a constitutionally admissible objective, i.e., containment of the spread of the contagious disease COVID-19 and thus the protection of human health and life, which this disease puts at risk. In its assessment of the proportionality of the interference with freedom of movement, the Constitutional Court held that the prohibition of movement outside the municipality of one's permanent or temporary residence was an appropriate measure for achieving the pursued objective. The Court held that there existed the requisite probability that - according to the data available at the time of the adoption of the challenged ordinances - it could have contributed towards reducing or slowing down the spread of COVID-19, primarily by reducing the number of actual contacts between persons living in areas with a higher number of infections and consequently at a higher risk of transmission of the infection. In the review of the necessity of the interference, the Constitutional Court deemed it crucial that the previously adopted measures (i.e., the closure of educational institutions, the suspension of public transport and the general prohibition of movement and gatherings in public places and areas) did not in themselves enable, at the time of the adoption of the challenged government's ordinances, the assessment that they would prevent the spread of infection to such an extent that - with regard to the actual systemic capacity - adequate health care could be provided to every patient. In such conditions, according to the Court, further measures to prevent the spread of infection and thereby the collapse of the health care system were necessary. Last but not least, the Constitutional Court assessed that the challenged restriction on movement was also proportionate in the narrower sense, which means that the demonstrated level of probability of a positive impact of the measure on the protection of human health and life outweighed the interference with the freedom of movement. 
In its assessment that the interference was proportionate in the narrower sense, the Constitutional Court deemed it important that the measure included several exceptions to the prohibition of movement outside the municipality of one's residence. ${ }^{56}$

In the constitutional complaint cases, the characteristics of decision-making depends on the features and peculiarities of proceedings in this type of cases. As explained in the section on the Constitutional Court's powers, prior to taking a decision on the merits of a case, the Court examines a constitutional complaint and decides in a panel of three judges at a closed session whether to initiate proceedings. The panel decides on the acceptance or rejection of the constitutional complaint in a fashion and according to criteria determined by the CCA. When deciding on the merits of a case, the Constitutional Court either dismisses a constitutional complaint as unfounded or grants it and in whole or in part annuls or abrogates the individual act, and remands the case to the authority competent to decide thereon (see above).

In the reasoning of its orders concerning the admissibility of a constitutional complaint, the Constitutional Court summarizes the proceedings before the courts of general jurisdiction, lists the decisions that are challenged by the constitutional complaint, presents the complainant's allegations and gives reasons for the decision regarding the admissibility of a constitutional complaint. It also clarifies the reasons for suspension if in the procedure for examining the constitutional complaint the challenged individual act has been temporary suspended.

In the reasoning of its final/substantive decisions, however, the Constitutional Court first summarizes once again the proceedings before the courts of general jurisdiction, lists the decisions that are challenged by the constitutional complaint and presents the complainant's allegations and arguments in more detail, while also referring to the challenged decisions and their statements. In these parts of the decision, understandably, the Constitutional Court's style of reasoning is predominantly illustrative and descriptive. The Constitutional Court then adjudicates on the merits of the case and provides a detailed argumentation of its decision. In order to decide on the matter, the Constitutional Court must first have the clear factual basis, which is then connected to the relevant law that has to be applied in the process of subsumption. In this part of the decision-making process, the Constitutional Court deploys different methods of interpretation of fundamental rights and other constitutional provisions and uses a broad range of arguments in order to substantiate its decision on the merits of a case. Here the style of reasoning of the Constitutional court becomes predominantly prescriptive and normative in its nature. Besides applying different methods/techniques of constitutional interpretation and argumentation, one of the main characteristics of the Constitutional Court's style of reasoning is the application of the proportionality and several other tests, standards and argumentative forms of review, depending on the case at hand. The aim of such reasoning is

56 U-I-83/20. The decision was adopted by five votes to four. The four judges who voted against the majority decision gave dissenting opinions. Four out of five judges who voted for the majority decision gave concurring opinions. 
to provide a convincing justification for the decision and to demonstrate the rationality of the decision-making process. Similar characteristics and style of reasoning can be observed in norm control proceedings. ${ }^{57}$

The common course of considering a constitutional complaint by the Constitutional Court is well illustrated, for example, in the decision number Up-879/14. In this »case of all cases « in the Slovenian judicial practice, the Constitutional Court decided on the constitutional complaint of Mr Janez Janša, the current Slovenian prime minister, who was at that time the leader of the strongest oppositional political party. The Ljubljana Local Court found Mr Janša guilty of the commission of the criminal offence of accepting a gift for unlawful intervention under the first paragraph of Article 269 of the Criminal Code. It sentenced him to two years in prison and imposed an accessory penalty of a fine in the amount of EUR 37,000.00, and required him to pay the costs of the criminal proceedings and the court fee. After the Higher Court dismissed the appeal of the complainant's defence counsels, Mr Janša's defence counsels filed a request for the protection of legality against the final judgment which was dismissed by the Supreme Court. Finally, in proceedings to decide on the constitutional complaint of Mr Janša, the Constitutional Curt abrogated judgements of the three courts of a general jurisdiction and remanded the case to a different judge of the Ljubljana Local Court for new adjudication. ${ }^{58}$ In the reasoning of the decision, the Constitutional Court summarized the proceedings before the courts of general jurisdiction, listed the decisions that were challenged by the constitutional complaint, presented the complainant's allegations and arguments and gave reasons for both, the decision regarding the admissibility of the constitutional complaint and decision regarding suspension of the challenged judgements of the regular courts. In the main section of 26 pages of final decision's reasoning, the Constitutional Court repeated the key allegations and statements of the complainant, adjudicated on their merits and provided a detailed argumentation of the decision.

\subsection{Methods of interpretation}

Our review of the selected case law of the Constitutional Court was based on a modified standard classification of interpretive methods and arguments developed by the theory of legal argumentation, adapted according to the common methodology of the research project. ${ }^{59}$ We searched for typical examples of methods and their subtypes and for each of them we tried to determine the frequency of their use. The study revealed that, when reasoning its decisions and determining the meaning of the constitution in cases regarding fundamental rights, the Constitutional Court uses

57 The length of the Constitutional Court's final decisions and their reasoning depends on the substance and complexity of each individual case. The majority of final decisions of the Constitutional Court comprise on average between seven and fifteen pages.

58 Up-879/14, dated 20 April 2015.

59 See the introductory chapter to this monograph, pp. 41-59. See also Tóth, 2016, pp. 175-180 and Pavčnik, 2000, 2013. 2013a. 
a wide range of different methods/techniques of legal interpretation. We also found that sometimes the Constitutional Court combines different methods or their subtypes and that some methods and their sub-types typically appear as decisive ones, while others most commonly appear as defining and strengthening ones supporting the Constitutional Court's decisions.

\subsubsection{Grammatical (textual) interpretation}

The grammatical (textual) interpretation is a method of interpretation quite frequently used in the Slovenian constitutional judicial practice. In total, this method can be found in one form or another in all decisions from our sample of case law and has been deployed 105 times in total, which amounts to $11 \%$ of all identified instances of deployment of methods of interpretation (see Table 1, 1). We found that among different forms and types of this method, the Constitutional Court resorted most often to legal professional (dogmatic) interpretation and the interpretation based on ordinary meaning.

As a form of legal professional (dogmatic) interpretation, a simple conceptual dogmatic interpretation of the Constitution is contained in 27 decisions from our sample of case law, and altogether the Constitutional Court used this method 85 times (in $9 \%$ of all identified instances of deployment of methods) (see Table1, $1 / \mathrm{B} / \mathrm{a}$ ). By deploying this method of interpretation, the Constitutional Court uses a special legal meaning of words that is uniformly accepted and recognized by lawyers. ${ }^{60}$ An example of deploying this method of interpretation while directly interpreting the Constitution was found in the decision number U-I-40/12 where the Constitutional Court determined the possibility to establish a legal entity as one of the aspects of the freedom of association:

"In addition, one of the aspects of the freedom of association determined by the second paragraph of Article 42 of the Constitution is that individuals have the possibility to establish a legal entity in order to enable collective functioning in a field of common interests." 61

Occasionally, this method of interpretation is used by the Constitutional Court to determine the meaning of general legal terms or principles which are not contained or at least not directly expressed in the Constitution. In the same decision, for example, the Constitutional Court used a simple conceptual dogmatic interpretation by referring to a special legal meaning of words "legal entities" and determined their substance:

"/../ Legal entities are an artificial form within the legal order. Their establishment and functioning are derived from the human right to establish legal entities in order 
for natural persons to exercise their interests. However, it is also important for the existence of legal entities and for the normal performance of their activities for which they were established that they enjoy a certain inner circle that is protected and sheltered to a reasonable extent from outside intrusions. In this circle, members of their human substratum (partners, members, employees, management, etc.) can peacefully carry out the activities directed at the purpose for which the entity was established." 62

A simple conceptual dogmatic interpretation was identified also in the case number U-I-155/11, where the Constitutional Court reviewed the constitutionality of several provisions of the International Protection Act, which regulate the national safe third country concept and the safe European country concept. Referring to the right to judicial protection, the Constitutional Court stated that:

"From the right to judicial protection (the first paragraph of Article 23 of the Constitution) it follows that parties must have the possibility to submit the dispute to the court and that the court also decides on the merits in that dispute by a binding decision." 63

Less frequently used type of legal professional (dogmatic) interpretation is interpretation on the basis of legal principles. It was found in 7 decisions from our sample of case law and deployed 10 times in total (see Table 1, 1/B/b). The most picturesque example of deployment of this method of interpretation can be found in the decision number U-I-24/10 where the Constitutional Court took a position on important aspects of minor offence proceedings vis-à-vis criminal procedure. According to the Constitutional Court, a criminal court may not adopt a second decision on the merits against the same person for a criminal offence regarding which there already exists a final judicial decision (res iudicata) and it may not punish the same person for the same criminal offence twice. In principle, this safeguard must also be guaranteed when minor offence proceedings were already initiated and concluded with legal finality before the initiation of criminal proceedings. In item 17 of the reasoning of this decision, when interpreting the meaning of the principle of legal certainty as a component of the constitutional principle of the rule of law, the Constitutional Court referred to the general legal principles of res iudicata and ne bis in idem:

"According to the ECtHR, ensuring legal certainty requires respect for the principle of res iudicata or finality of court decisions, from which it follows that a party cannot, in the absence of special circumstances, request re-examination of such decisions /.../."64

62 U-I-40/12, dated 11 April 2013, item 20.

63 U-I-155/1, dated 18 December 201, item 37.

64 U-I-24/10, dated 19 April 2012, item 10. 
".../ it is evident that the challenged statutory provision can be constitutionally interpreted only in such a way that its application is admissible in cases when a misdemeanor procedure has been finalized against an individual, while in criminal proceedings with regard to the same historical event the court will find that it does not follow from facts that are identical or essentially the same as those which were the basis for the misdemeanor procedure. It will therefore be possible to conclude that both procedures are two different legal issues. A different interpretation of that statutory provision would constitute a breach of the ne bis in idem principle." ${ }^{65}$

This type of legal professional (dogmatic) interpretation was also used in the decision number Up-108/16, where the Constitutional Court established the legal meaning of the constitutional principle of application of a more lenient law, which is integrated in the principle of legality in criminal law (here, by referring to its own judicial practice, the Constitutional Court simultaneously deployed the method of interpretation of the Constitution on the basis of its case law):

"In accordance with the established constitutional review, the essence of the second paragraph of Article 28 of the Constitution lies in the enforcement of the principle of application of a more lenient law (lex mitior), which binds the court in interpreting laws if there are legal changes in determining criminal offense." 66

In contrast to other types of grammatical (textual) interpretation, the other professional interpretation was not used by the Constitutional Court in decisions from our sample of case law (see Table 1, 1/C).

As a form of the interpretation based on an ordinary meaning, a semantic interpretation was found in 10 decisions. It was used 12 times in aggregate, which amounts to $1 \%$ of all identified instances of deployment of methods (see Table 1 , 1/A/a). When using this technique of interpretation, the Constitutional Court applies the generally accepted meaning of the words and expressions of the constitutional norm in question within a given language. ${ }^{67}$

In the decision number Up-1006/13, for example, the Constitutional Court explained the substance of (the right to) privacy as provided for in Article 35 of the Convention by giving the generally accepted meaning to the notion of privacy:

"The right to privacy determines the area of an individual's own activity in which he or she is the one who decides which intrusions he or she will allow."

65 U-I-24/10, item 17.

66 Up-108/16, dated 6 December 2017, item 6.

67 See the introductory chapter to this monograph, p. 42 .

68 Up-1006/13, dated 9 June 2016, item 11. 
Similarly, in the decision number Up-444/09, the Constitutional Court determined the limits of freedom of expression vis-à-vis the right to respect for private and family life. The Constitutional Court discovered, inter alia, the generally accepted meaning of the words and expressions of the constitutional provision on the freedom of expression of thought by stating the following:

/.../ In the first paragraph of Article 39, the Constitution guarantees the freedom of expression of thought, speech and public appearance, the press and other forms of public information and expression. Everyone is free to collect, accept and spread conscience and opinions. $/ \ldots /{ }^{69}$

In the selected decisions we have not found a single case where the Constitutional Court would use a syntactic interpretation (see Table 1, 1/A/b).

\subsubsection{Logical arguments}

As a method of interpretation, logical arguments were not used very often in the selected case law of the Slovenian Constitutional Court. They were identified in 3 decisions where they were deployed 6 times altogether (see Table 1, 2). In 2 decisions from our sample of case law the Constitutional Court used argumentum a maiore ad minus, having made an inference from more to less (see Table 1, 2/B).

For example, when determining the level of the constitutional protection of legal entities, the Constitutional Court held, inter alia, the following:

"\%../ As legal entities are artificial forms which are constitutionally protected in order for the sphere of individuals' freedom to be widened and protected, the level of their protection can from the outset be lower than the level of protection of natural persons." 70

"Such is due to the legal nature of legal entities. In the wider, outer circle of the expected privacy, the legal entity cannot expect privacy which in terms of its quality would correspond to the privacy that, under the first paragraph of Article 36 of the Constitution, is provided, with regard to its spatial aspect, to natural persons. In the inner, narrower circle of such privacy, also a legal entity can expect the same constitutional protection of spatial privacy as a natural person." ${ }^{11}$

Another type of logical interpretation, which was identified in one decision from our sample of case law, is argumentum a contrario (see Table 1,2/D). The Constitutional Court deployed this argument explicitly in its decision number U-I-109/10. 
Defining the essence of the constitutional principle of democracy in connection with fundamental rights, the Constitutional Court stated:

\begin{abstract}
"The principle of democracy (with which other constitutional principles /.../ are most closely connected), goes beyond the definition of a state as merely formal democracy where laws and regulations are adopted by a majority rule. On the contrary, the principle of democracy defines the Republic of Slovenia as a constitutional democracy, i.e., as a state in which the conduct of authorities is legally limited by constitutional principles and human rights and fundamental freedoms, precisely because individual and his or her dignity are at the heart of its existence and operation."72
\end{abstract}

\title{
3.2.3. Domestic systemic arguments
}

Domestic systemic arguments are the most frequently used interpretative tool in our sample of Constitutional Court's decisions. Altogether, different types and sub-types of this method can be found in all decisions from our sample of case law and have been deployed 494 times in total, which amounts to $50 \%$ of all identified instances of deployment of arguments and methods of constitutional interpretation (see Table 1, 3).

The most frequently deployed method among domestic systemic arguments was the interpretation on the basis of case law of the Constitutional Court (see Table $1,3 / C)$. Regarding this method of interpretation, the most frequently used are references to specific previous decisions of the Constitutional Court as precedents. This interpretative tool was found in all decisions from our sample and has been deployed 280 times in total, which amounts to $28 \%$ of all identified instances of deployment of methods (see Table 1, 3/C/a).

In our sample of case law, the Constitutional Court made the highest total number of references to its specific previous decisions in the decision number Up-879/14. In this decision, the Constitutional Court decided on the constitutional complaint of the Bar Association of Slovenia against Ljubljana District Court Orders issuing house search of the offices of three attorneys. The Constitutional Court held that the investigative measures conducted on the basis of the district court orders violated the rights determined by Article 35 (the rights to privacy and personality rights), the first paragraph of Article 36 (inviolability of dwellings), and the first paragraph of Article 37 (the right to privacy of correspondence and other means of communication), as well as the rights determined by the first paragraph of Article 23 (the right to judicial protection) and Article 25 (the right to legal remedies) of the Constitution. The Constitutional Court prohibited further interferences with the privacy of attorneys on the basis of the orders referred to in this decision. Also, the investigative measures may not be conducted without the attendance of a representative of the Bar Association of Slovenia or without observing the safeguards that follow from 
the Constitutional Courts' decision. According to the Constitutional Court, the complainants against whom investigative measures have been conducted, their attorneys or representatives, and a representative of the Bar Association of Slovenia must immediately be granted access to all objects, data, documents, and documentation that have been seized during investigative measures against the complainants. Also, the complainants and the representative of the Bar Association of Slovenia have the right to object to their seizure in the manner and according to the procedure determined by the Constitutional Court. ${ }^{73}$ Additionally, the Constitutional Court ruled that Criminal Procedure Act and the Attorneys Act are inconsistent with the Constitution and that the National Assembly must remedy the unconstitutionality within one year. ${ }^{74}$

In this decision alone, there are references to more than thirty previous decisions of the Constitutional Court. For example, while defining a person's privacy as sthe sphere of a person's existence formed by a more or less complete whole of his or her conduct and engagements, feelings, and relations, for which it is characteristic and essential that the person shapes and maintains it alone or together with those close to him or her with whom he/she lives in an intimate community, for example with a spouse, and that he/she lives in such community with a sense of being safe from intrusion by the public or any other undesired person«, the Constitutional Court makes reference to its previous decision number Up-32/94. And while stating that the duty to protect the confidentiality of what a client has entrusted to them establishes not only attorneys' obligation to protect confidentiality, but also attorneys' right to be free from interferences with the privacy of attorneys, and that this right is reflected in the obligation of others, primarily the state, to abstain from such interferences, the Constitutional Court makes reference to its previous decision number U-II-1/09. ${ }^{75}$

While in some occasions, the Constitutional Court referred to specific previous decisions by citing them in the main text of the reasoning, in other occasions it did so by citing them in footnotes. Here are some examples which illustrate how the Constitutional Court used one or another "technique" of citing its previous decisions:

73 In the reasoning the Constitutioal Court stated that the decision of a judge rejecting the exclusion of data contained in documents or other storage media from the scope of an investigative measure may be appealed within three days of the service of the judge's decision. The appeal may be lodged by the attorney or the representative of the Bar Association of Slovenia, who requested the exclusion during the execution of the investigative measure in order to protect the privacy of attorneys. The appeal may invoke complaints regarding the constitutionality or legality of the court order authorising an investigative measure and request protection against the review and disclosure of data that are protected by the privacy of attorneys and therefore the review of such data and the seizure of the media on which it is stored are inadmissible. The competent higher court shall decide on the appeal within three days of its receipt by means of an order served on the complainant and the investigating judge, as well as the police if the investigating judge authorised the police to execute the investigative measure. The appeal suspends the effect of the judge's decision rejecting the exclusion of data from the scope of the investigative measures. See Up-879/14.

74 Up-879/14.

75 Up-879/14. 
"Already in Decision No. U-I-425/06, dated 2 July 2009 (Official Gazette RS, No. 55/09, and OdlUS XVIII, 29), wherein it compared the position of a spouse and the position of a registered partner with regard to inheritance in the event of their partner's death, the Constitutional Court clearly defined the criteria for the review of allegations of discriminatory treatment, which are also applicable in the case at issue."76

"Referring to the aforementioned provisions of the Constitution and international instruments for the protection of human rights, the Constitutional Court has alrea decision No. Up-134/97 of 14 March 2002 stated that the essence of the privilege against self-incrimination in connection with the prohibition of extortion of confessions is that law enforcement authorities in the broadest sense must leave the defendant completely passive, so that he or she can consciously, reasonably and above all voluntarily decide whether to cooperate with them or not."77

"The first paragraph of Article 14 of the Constitution prohibits discrimination in ensuring, exercising, and protecting human rights and fundamental freedoms regarding an individual's personal circumstances. In order to establish a violation of the constitutional prohibition of discriminatory treatment, the determination of the existence of inadmissible discrimination in the enjoyment of any human right suffices, whereby it is not necessary to demonstrate an interference with this human right in and of itself [footnote]." 78

"The Constitutional Court has repeatedly established the incompatibility of the former communist regime with European standards for the protection of human rights and fundamental freedoms, to which the Republic of Slovenia is also bound [footnote]."79

In 16 decisions from our sample, the Constitutional Court made references to its own judicial practice in a general manner (i.e., without making references to specific previous decisions).

This interpretative technique has been deployed 25 times in total, which amounts to $3 \%$ of all identified instances of deployment of interpretative methods in the selected case law of the Slovenian Constitutional Court (see Table 1, 3/C/b). For example, in its decisions number Up-457/09, U-I-292/09, Up-1427/09 and Up-450/15, the Constitutional Court, when interpreting the constitutional provisions, made references to its previous judicial review in a general manner in the following fashion:

"/.../ In the constitutional review, a position on the specially protected position of denationalization beneficiaries was established. Their rights derive from their constitutionally protected specific civil legal entitlements to their former property, arising

76 U-I-212/10, dated 14 March 2013, item 7.

77 Up-1293, item 31.

78 Up-1293, item 38. In a footnote the Constitutional Court referred to its previous decisions No. U-I146/07, dated 13 November 2008 and U-I-425/06 dated 2 July 2009.

79 U-I-109/10, dated 26 September 2011, item 17. In a footnote the Constitutional Court referred to its previous decisions No. U-I-69/92, dated 10 December 1992, No. U-I-158/94, dated 9 March 1995, No. Up-301/96, dated 15 January 1998 and No. U-I-248/96, dated 30 September 1998. 
from Article 33 of the Constitution. Any subsequent interference with the right to denationalization is an interference with the human right to private property and inheritance from Article 33 of the Constitution." 80

"/.../ According to the established position of the Constitutional Court, this article prohibits that a person in respect of whom there is a real danger that he or she would be subjected to inhuman treatment in the event of return to the country of origin, would be extradited to that country." 1

"/.../ According to the established constitutional review, a violation of a human right from Article 26 of the Constitution occurs when the court bases its decision on a legal position which is unacceptable from the point of view of this right." ${ }^{2}$

In all the above examples, the Constitutional Court combined the use of the interpretative technique of referring to its own judicial practice in a general manner with the use of the contextual interpretation in a narrow sense (see below).

In the decisions contained in our sample, the Constitutional Court, when interpreting constitutional provisions on fundamental rights, did not make references to its rules of procedure or other abstract norms formed by itself (see Table 1, 3/C/c).

In comparison with the interpretation of the constitution on the basis of case law of the Constitutional Court, the frequency and weight of other types of domestic systemic arguments and methods of constitutional interpretation is significantly smaller. To be precise, even though a contextual interpretation (in a narrow and broad sense) occurs in nearly all decisions from our sample (e.g. in 29 out of 30), this method was applied three times less often than references to specific previous decisions of the Constitutional Court. In total, this method was used in 89 occasions, which amounts to $9 \%$ of all identified instances of deployment of methods and arguments (see Table 1, 3/A). When used in a broad sense, this domestic systemic argument is deployed when a constitutional court determines the meaning of a given constitutional provision with respect to other specific constitutional provisions. It includes references to and comparison with fundamental rights stipulated in the constitution or other constitutional provisions. In a narrow sense, however, contextual interpretation is used when a constitutional court explores the meaning of the constitutional provision on the basis of its purpose which merely follows from its place in the system of legal norms, without comparing it with other specific constitutional/ legal provisions. ${ }^{83}$ It is used in order to materially concretize, specify and "fill in" often very vague constitutional provisions.

Our review revealed that in the selected cases the Constitutional Curt deployed a contextual interpretation in a broad sense more frequently than in a narrow sense. Here are some examples of the use of one or another:

80 See Up-457/09, dated 28 September 2011, item 9.

81 U-I-292/09, Up-1427/09, dated 20 October 2011, item 13.

82 U-I-292/09, Up-1427/09, item 6.

83 See the introductory chapter to this monograph, p. 51. 
“/... In Article 35, the Constitution guarantees the inviolability of a person's physical and mental integrity, and the inviolability of his privacy and personality rights. In addition to this general provision on the protection of privacy, it also includes three special provisions which specifically protect the inviolability of dwellings (the first paragraph of Article 36 of the Constitution), the privacy of correspondence and other means of communication (the first paragraph of Article 37 of the Constitution), and the protection of personal data (the first paragraph of Article 38 of the Constitution)." 84 "/.../ The legal entities to which the constitutional assessment at issue applies are established for the purpose of exercising an economic activity. The Constitution expressly prohibits that the economic activity is exercised contrary to the public benefit (the second sentence of the second paragraph of Article 74 of the Constitution), and equally expressly prohibits acts of unfair competition, as well as acts which contrary to law limit competition (the third paragraph of Article 74 of the Constitution). These constitutional prohibitions, which are also the basis for limitations of the right to free economic initiative (the first paragraph of Article 74 of the Constitution), require appropriate action by the legislature. In certain instances, they can be joined by other constitutional requirements, such as the authorisation of the legislature to determine the conditions and manner of exercising economic activity so as to ensure a healthy living environment (the second paragraph of Article 72 of the Constitution)." 85 "/.../In addition to Article 35 of the Constitution, it is especially the first paragraph of Article 37 of the Constitution that protects the communication aspect of privacy." 86 "The reasoning of a court decision is an independent and autonomous element of the right to a fair trial, which - within the framework of the right to equal protection of rights - is guaranteed by Article 22 of the Constitution." ${ }^{87}$

In the case number Up-1056/11, the Constitutional Court has taken a precedent position on the issue of submission, by a national court, of a case to the ECJ for a preliminary ruling. According to the Constitutional Court, the Supreme Court must take a sufficiently clear position with regard to the question of interpretation of European Union law and/or the validity of secondary European Union law, which entails that it must adopt a position with regard to the party's motion to submit the case to the Court of Justice of the European Union for a preliminary ruling. This reasoning must be such as to enable an assessment from the viewpoint of the first paragraph of Article 23 of the Constitution and thus an assessment [by the Constitution Court] whether [the Supreme Court] respected or disregarded the conditions for the submission of the case to the Court of Justice of the European Union under Article 267 of the Treaty on the Functioning of the European Union. In this decision, the Constitutional Court deployed contextual interpretation in a broad sense by determining the meaning of a 
particular constitutional provision with respect to other specific constitutional provisions (and provisions of the Treaty on the Functioning of the European Union):

"Respect for the first paragraph of Article 23 of the Constitution in relation to the third paragraph of Article 3a of the Constitution and the third paragraph of Article 267 of the TFEU presupposes that the Court of Justice of the European Union is a court in the sense of the first paragraph of Article 23 of the Constitution and that the Supreme Court was obliged, as a court in the sense of the third paragraph of Article 267 of the TFEU, to submit the case to the Court of Justice of the European Union, under the presumption that the question regarding the interpretation of European Union law is essential for the decision, with regard to which the case law of the Court of Justice of the European Union has not yet delivered an answer thereon. Consequently, the Constitutional Court first had to assess whether the mentioned conditions are fulfilled." 88

In one of the cases included in our sample, the Constitutional Court deployed a "derogatory formulae", albeit not for the purpose of a direct interpretation of the Constitution. When applying provisions of laws and other legal acts, this interpretative tool provides guidance for choosing the applicable stipulation from contradictory ones. Resolving conflict of norms stipulated in the Criminal procedure Act and Protection of Documents and Archives and Archival Institutions Act, the Constitutional Court has applyed a derogatory formulae (i.e., the argument of speciality):

"The wording of the first paragraph of Article 154 of the Criminal Procedure Act forces to the conclusion that the results of covered investigative measures can only be kept by a "court", and never by another body, organization or individual. Despite the fact that the first paragraph of Article 40 of the Protection of Documents and Archives and Archival Institutions Act could lead to a different interpretation for those findings of covered investigative measures that might correspond to the definition of archival material, (footnote) the contradiction between it and the first paragraph of Article 154 of the Criminal Procedure Act can be resolved by the argument of specialty (lex specialis derogat legi generali). The Criminal procedure Act is an older and more special law. (footnote) Therefore, Protection of Documents and Archives and Archival Institutions Act, as a younger and more general law, cannot in this case repeal the prohibition from the Criminal Procedure Act to keep sensitive material obtained through measures that secretly and covertly infringe on human rights and freedoms somewhere other than in court /.../."89

The interpretation of constitutional norms on the basis of domestic statutory law as another type of domestic systemic arguments occurs in 18 decisions 
from our sample of case law (see Table 1, 3/B). The weight of this interpretative tool, however, is even smaller than the one of the contextual interpretation in a narrow and/or broad sense. According to our statistical survey, this interpretative technique has occurred in $7 \%$ of all identified instances of deployment of methods (e.g. 50 times in total, while the contextual interpretation in a narrow and/or broad sense appeared 89 times). In the decision U-I-152/17, the Constitutional Court interpreted the constitutional provisions on the right to protection of personal data in light of statutory norms, i.e., in light of the provisions of the Personal Data Protection Act.

"From the CPIAPPD, Directive 2016/680, and the Personal Data Protection Act (Official Gazette RS, No. 94/07 - official consolidated text - hereinafter referred to as the PDPA-1), all of which adopted a broad, all-inclusive definition, it follows that personal data are any information regarding a determined or determinable individual; a determinable individual is someone who can be determined either directly or indirectly.[footnote] Accordingly, the challenged regulation envisages the processing of personal data. Namely, licence plate data (together with the date, location, and time when a photograph was taken) [footnote] entail personal data because they refer to information regarding the vehicle of a determined or determinable individual. Since the purpose of the measure inter alia also includes the elimination of persons from traffic who do not fulfil the conditions to use roads and the search for persons, it is obvious that licence plate data is intended precisely to identify individuals and thus entails personal data, in conformity with the definition mentioned above." 90

Another example of interpretation of constitutional norms on the basis of domestic statutory law was found in the decision number Up-1006/13. In this case, the meaning of the constitutional provision on equal protection of rights was interpreted by the Constitutional Court with a reference to provisions of the Criminal Procedure Act on the right to a reasoned court order:

"/... However, the right to a reasoned court order is not merely a statutory right, but is also a constitutionally determined and protected human right enshrined in Article 22 of the Constitution. The fact that the reasoning of an order authorising a search of premises is substantively empty constitutes not only a breach of the statutory requirement of a reasoned order determined by the first paragraph of Article 215 of the CrPA, but also a violation of the constitutional human right determined by Article 22 of the Constitution." ${ }^{\prime 1}$

While the interpretation on the basis of normative acts of other domestic state organs has not been used at all (see Table 1,3/E), the Constitutional Court referred to the case law of ordinary courts in 6 decisions from our sample of case 
law (see Table 1, 3/D).$^{92}$ As a method, the interpretation on the basis of the case law of ordinary courts (e.g. courts of general jurisdiction) was used 22 times in total, which amounts to less than $2 \%$ of all instances of deployment of methods and arguments. Interestingly, the majority (14) of references to the case law of ordinary court was made in the case number Up-1006/13. Most references were made to specific individual decisions of ordinary courts. In item 14 of the reasoning of this decision, the Constitutional Court, when determining the constitutional conditions for a lawful search of premises, drew inferences from the case law of the Supreme Court by making a footnote where two Supreme Court judgements have been cited. The Constitutional Court held:

"It follows from the case law that an order authorising a search of premises must also contain information on the person against whom the search is to be conducted and it must identify the suspect and the premises that will be searched (footnote)." ${ }^{93}$

Similarly, in item 20 of the same decision, the Constitutional Court addressed the right to privacy and determined the conditions of the constitutional admissibility of issuing an order authorising a search of premises by referring to the Supreme Court's decision cited in a footnote:

"As stated in Paragraphs 11 and 12 of the reasoning of this Decision, a search of premises entails a severe interference with the human right to privacy determined by the first paragraph of Article 36 of the Constitution. Therefore, the court must review in advance, i.e. before issuing an order authorising a search of premises, whether the conditions for a search of premises are fulfilled. A judge's consideration of a case is reflected in the reasoned order authorising a search of premises, in which the judge must clarify on what basis he or she deems that there exist reasonable grounds for the suspicion that a specific person committed a criminal offence as well as why he or she deems that it is likely that the objects sought will be found precisely in the possession of a specific person and at a specific address (footnote)." ${ }^{94}$

An example of interpretation referring to the practice of ordinary courts en général (e.g. without citing single case decisions) was identified in item 23 of the reasoning of the same decision where the Constitutional Court stated:

"Although the Supreme Court held that the deficient reasoning undoubtedly entailed a violation of the first paragraph of Article 215 of the Criminal Procedure Act,

92 While in almost all decsions from our sample the Constitutional Court referred to the case law of ordinary courts when summarizing the proceedings before the regular courts and listing their decisions, it did so significantly less often when interpreting fundamental rights.

93 Up-1006/13, item 14.

94 Up-1006/13, item 20. 
according to its position, this deficiency does not entail that the evidence produced by the search is inadmissible." 95

\subsubsection{External systemic and comparative law arguments}

The second most commonly used interpretative tool in the Slovenian constitutional judicial practice are external systemic and comparative law arguments. In our sample of case law, this method has been found, in one or another form, in all decisions from our sample of case law and deployed in $24 \%$ of all identified instances of deployment of main methods of constitutional interpretation (see Table 1, 4). It shall be noted however, that not all types of external and comparative law arguments are used with equal frequency and that they do not hold equal weight in the interpretative practice of the Slovenian Constitutional Court.

The most frequently deployed type is the interpretation of fundamental rights on the basis of judicial practice of international courts. Understandably, this method of interpretation is contained in all decisions from our sample of case law as references to the ECtHR and/or ECJ judgement(s) have been one of the main criteria for the selection of the Constitutional Court's cases included in the research. In overall, however, in the selected decisions references to judicial practice of international courts occurred 158 times, which amounts to $16 \%$ of all identified instances of deployment of arguments and methods (see Table 1, 4/B). $81 \%$ of all references to judicial practice of international courts were made to individual case decisions of the ECtHR and $19 \%$ of references were made to the case law of the ECJ. In the decisions from our sample of case law, the Constitutional Court made no reference to judicial practice of other international courts.

The Constitutional Court's decision number Up-1056/11 contains 26 references to decisions of both the ECtHR and ECJ, however, most references were made to specific individual cases of the ECJ. In item 6 of the reasoning of the decision, for example, the Constitutional Court referred to the ECJ case law in general terms in the main text and made explicit reference to its judgement C.I.L.F.I.T., 283/81 in a footnote:

\footnotetext{
"When in proceedings it is conducting a national court is faced with a question whose resolution falls within the exclusive jurisdiction of the Court of Justice of the European Union, it must not decide thereon unless the Court of Justice of the European Union has already answered it or other conditions that allow the national court to adopt a decision are fulfilled [footnote]." ${ }^{96}$
}

When determining in length the legal nature of the ECJ in terms of the constitutional definition of an independent and impartial court constituted by law in item 9 
of the reasoning, the Constitutional Court referred to several individual decisions of the ECJ in a footnote:

"The Court of Justice of the European Union is a court in the sense of an independent, impartial court constituted by law as referred to in the first paragraph of Article 23 of the Constitution. With regard to extensive institutional provisions (especially Articles 13 and 19 of the Treaty on European Union, consolidated version, OJ C 326, 26 October 2012 - hereinafter referred to as the TEU; Articles 251 through 256 of the TFEU and Protocol (No. 3) on the Statute of the Court of Justice of the European Union), there cannot be any doubt that in terms of its characteristics, the Court of Justice of the European Union is a court in the sense of the first paragraph of Article 23 of the Constitution. Not even the fact that the procedure under Article 267 of the TFEU is an intermediary procedure [footnote] that the parties to original proceedings before the court of a Member State cannot initiate by themselves, nor the fact that the main purpose of such procedure is to (merely) interpret of European Union law and/ or assess the validity of secondary European Union law, can influence such characterisation. The answer to a question regarding the interpretation of the Treaties and/ or the validity and interpretation of legal acts adopted on their basis is of essential importance for the adoption of the final decision in a single judicial dispute, a part of which is also a motion for a preliminary ruling. The right of an individual who is party to original proceedings [before the court of a Member State] to judicial protection under the first paragraph of Article 23 of the Constitution refers also to the duty of a court to submit the case to the Court of Justice of the European Union on the basis of Article 267 of the TFEU, regardless of the type of original judicial proceedings." ${ }^{\prime 97}$

Another quite frequently deployed method among external systemic arguments is the interpretation of fundamental rights on the basis of international treaties. This method was identified in 21 decisions from our sample of case law and there are altogether 61 references to international treaties. This amounts to $6 \%$ of all identified instances of deployment of arguments and methods of interpretation (see Table 1, 4/A). In the selected decisions, most references were made to the European Convention on Human Rights, while significantly less frequently the Constitutional Court referred to the Charter of Fundamental Rights of the European Union. In our sample of its case law, the Constitutional Court also made references to other international treaties. ${ }^{98}$

97 Up-1056/11, item 9.

98 In addition to the ECHR and the Charter, the Constitutional Court referred to the following international treaties and international and EU legal sources: Convention implementing the Schengen Agreement, Charter of the United Nations (1945), Universal Declaration of Human Rights (1948), International Covenant on Civil and Political Rights (1976), International Covenant on Economic, Social and Cultural Rights (1976), United Nations Convention on the Rights of the Child, Geneva Conventions (1949), Convention on the Civil Aspects of International Child Abduction, European Convention on the Exercise of Children's Rights, Resolution 1481/2006 of the Council of Europe 
In the above cited item 9 of the reasoning of the decision number Up-1056/11, for example, the Constitutional Court referred to the Treaty on European Union and the Treaty on the Functioning of the European Union as well as to the Protocol (No. 3) on the Statute of the Court of Justice of the European Union (see supra).

The comparative law arguments, i.e., references to norms or case decisions of foreign legal systems, were identified in 8 decisions from our sample of case law and there are altogether 12 references to either constitutions and other normative acts or court decisions of foreign legal systems. This amounts to less than $1 \%$ of all identified instances of deployment of arguments and methods of interpretation (see Table 1, 4/C). For example, reviewing in the decision number U-I-83/20 the constitutionality of the COVID-19 measures (i.e., the prohibition of movement outside the municipalities of one's residence), the Constitutional Court referred to the decision of the German Federal Constitutional Court in Order No. 1 BvR 1021/20, dated 13 May 2020 and decision of the Bayerischer Verfassungsgerichtshof No. Vf.6-VII-20, dated 26 March 2020. ${ }^{99}$

\subsubsection{Teleological interpretation}

The teleological interpretation, in wider context, includes all arguments referring to the purpose, meaning, function, aim, etc. of the Constitution. ${ }^{100}$ For this reason, in the case law of the Slovenian Constitutional Court, usually teleological interpretation is implied in or fused with other methods of interpretation and it is sometimes difficult to draw a line between the methods. In a narrow sense, however, this method is deployed by the Constitutional Court if and when it refers, either explicitly or implicitly, to the purpose of the Constitution and its individual provisions. ${ }^{101}$

Considering it in a narrow sense, the teleological interpretation was found in 9 decisions from our sample of case law. Altogether, it was deployed 24 times which amounts to $2 \%$ of all identified instances of deployment of arguments and methods of interpretation (see Table 1,5). Explicit references to the purpose of the constitutional

Parliamentary Assembly, Convention for the Protection of Individuals with Automatic Processing of Personal Data, Treaty on European Union and the Treaty on the Functioning of the European Union, Protocol (No. 3) on the Statute of the Court of Justice of the European Union, European Parliament resolution of 2 April 2009 on European conscience and totalitarianism, Council Regulation (EC) No. 343/2003, of 18 February 2003, Regulation (EU) No 604/2013 (Dublin III Regulation), Directive 2011/95/EU of the European Parliament and of the Council, Council Directive 2005/85/EC of 1 December 2005 on minimum standards on procedures in Member States for granting and withdrawing refugee status, Council Directive 2004/83/EC of 29 April 2004 on minimum standards for the qualification and status of third country nationals or stateless persons as refugees or as persons who otherwise need international protection and the content of the protection granted, Directive 2013/48/EU of the European Parliament and of the Council of 22 October 2013 on the right of access to a lawyer in criminal proceedings and in European arrest warrant proceedings, and on the right to have a third party informed upon deprivation of liberty and to communicate with third persons and with consular authorities while deprived of liberty, Asylum Procedures Directive, etc.

99 U-I-83/20, item 43.

100 See the introductory chapter to this monograph, p. 53.

101 Sometimes the goal of the Constitution is an explicit part of the text of the constitution. 
provisions on fundamental rights and principles occurred in the decision number U-I-109/10 where the Constitutional Court held:

"As a fundamental value, human dignity has a normative expression in many provisions of the Constitution, in particular it is concretized through provisions guaranteeing individual human rights and fundamental freedoms; these are intended precisely to protect various aspects of human dignity." 102

"\%../ the principle of democracy defines the Republic of Slovenia as a constitutional democracy, i.e., as a state in which the conduct of authorities is legally limited by constitutional principles and human rights and fundamental freedoms, precisely because individual and his or her dignity are at the heart of its existence and operation. In a constitutional democracy, an individual is a subject and not an object of the state action and his or her (self) realization as a human being is the fundamental purpose of a democratic order. Only such a state system is truly democratic, in which respect for human dignity is the fundamental guideline for the functioning of the state." ${ }^{103}$

As argued, the teleological interpretation may be deployed implicitly. Considering whether to review the constitutionality of the government's decree which during proceedings before the Constitutional Court ceased to be in force, the Constitutional Court held:

"\%...The establishment of legal predictability of the actions of the competent state authorities and, above all, the concern for ensuring respect for constitutional values, in particular human rights and fundamental freedoms as a basis of the constitutional order (Preamble to the Constitution), therefore justify the public interest and shall be considered an exception to the second paragraph of Article 47 of the Constitutional Court Act." 104

\subsubsection{Historical interpretation}

The historical interpretation is another method of interpretation which is not very common in the constitutional judicial practice in Slovenia. More precisely, in the selected decisions of the Constitutional Court, this interpretative tool was found in one decision (see Table 1, 6), in which the Constitutional Court made, implicitly, a general reference to the intention, will etc. of the constitution-maker (see Table 1, 6/C). In item 18 of the decision number U-I-109/10, stating that the reintroduction of a street named after Josip Broz Tito, a symbol of the Yugoslav communist regime, was contrary to the values on which the Constitution was based, the Constitutional Court stated: 
"In Slovenia, where the development of democracy and free society based on respect for human dignity began with the break up with the former system, whereby this break-up is clearly evident also at the constitutional level (first with the amendments to the Constitution of the Socialist Republic of Slovenia and subsequently with the adoption of the BCC and the Constitution, as the fundamental constitutional documents), the glorification of the communist totalitarian regime by the authorities by naming a street after the leader of such regime is unconstitutional. Such new naming of a street no longer has a place here and now, as it is contrary to the principle of respect for human dignity, which is at the very core of the constitutional order of the Republic of Slovenia. Naming a street after Josip Broz Tito namely does not entail preserving a name from the former system and which today would only be a part of history. The challenged Ordinance was issued in 2009, eighteen years after Slovenia declared independence and established the constitutional order, which is based on constitutional values that are the opposite of the values of the regime before independence. Not only the victims or opponents of the former regime, but also other members of the public can understand such act of the authority at issue in the present time as newly emerged official support for the former communist regime. Such act is contrary to the values on which the Constitution is based." 105

In the same decision, trying to determine the substance of human dignity as a fundamental constitutional value in the democratic Slovenia, the Constitutional Court held:

“/../ a firm and comprehensive a priori definition of human dignity is not possible, because in addition to constitutional and international legal standards, it is also filled with historical and ethical contents, which develop and upgrade over time."106

\subsubsection{Arguments based on scholarly works}

The third most frequently used interpretative arguments are those based on scholarly works. In the selected decisions of the Slovenian Constitutional Court, this main type method was identified in 25 decisions, and the Constitutional Court made 102 references of this kind in aggregate. The latter amounts to $10 \%$ of all identified instances of deployment of arguments and methods (see Table 1, 7). While the largest share of references (52\%) were made to the scientific monographs, the Constitutional Court also made references to the scientific articles (22\%) and to the commentaries (26\%). Among these, 15 references (38\%) were made to the commentaries of the Constitution, 19 references (49\%) to the commentaries of statutory law and 5 references (13\%) to the commentaries of EU regulations and directives. No reference was made to the previous constitutions being no longer in force. 
Explaining the essence of the privilege against self-incrimination in item 31 of the decision number Up-1293/08, the Constitutional Court referred in a footnote to a scientific monograph on the prohibitions of evidence in criminal proceedings:

"\%.../ Thus, this constitutional procedural guarantee prevents the state from forcing the individual to become a source of evidence against himself. The essence of the privilege against self-incrimination is to preserve the defendant's procedural subjectivity and thus a fair trial. [footnote]." 107

In item 12 of the decision number U-I-292/09, Up-1427/09, the Constitutional Court referred in a footnote to a scientific article when addressing the international legal principle of non-refoulment as a component of the constitutional right of asylum:

"\%../The principle of non-refoulment to countries where they are in danger of persecution or where their life or personal integrity is otherwise threatened is a widely recognized international principle [footnote]."

A typical example of the Constitutional Court's reference to a commentary of the Constitution can be found in item 10 of the decision number Up-457/09:

"Article 33 of the Constitution in itself guarantees confidence in a certain permanence, stability and immutability of the acquired property right. For the purpose of the present case, the principle of finality from Article 158 of the Constitution must also be emphasized. This principle stipulates that legal relations regulated by a final decision of a state body may be revoked, annulled or changed in cases and in accordance with the procedure determined by law. The provision ensures the invariability of legal relations regulated by individual administrative or judicial acts. The right acquired by an individual act or an obligation thus imposed should no longer be encroached upon, as this would undermine confidence in the legal order [footnote]."

\subsubsection{Interpretation in light of general legal principles}

As a method of legal interpretation, the interpretation in light of general legal principles includes legal principles which determine the functioning of the whole or part of legal system, while they are not expressed in the text of the Constitution. It was found in 4 decisions from our sample of case law. Altogether, it was deployed 11 times which amounts to $1 \%$ of all identified instances of deployment of methods of interpretation (see Table 1, 8).

An example of deployment of this method of interpretation can be found in the decision number Up-879/14. As indicated earlier, in this decision the Constitutional Court overturned a criminal conviction of the current Slovenian prime minister. 
The decision has had (and still has) a significant impact on the prosecution of perpetrators of crimes of corruption in Slovenia. In items 20 and 21 of the decision, the Constitutional Court interpreted the Constitution in light of general legal principles of lex scripta and lex certa:

"As in accordance with the lex scripta requirement criminal offences may be determined exclusively by the legislature by law, this constitutional requirement importantly supplements the general constitutional law relationship between the legislative power, which adopts the laws, and the judicial power, which interprets them (the second paragraph of Article 3 of the Constitution) /.../."108

"The lex certa requirement entails that a criminal law must be definite, certain, clear, and predictable, which, on one hand, is a question of the objective semantic precision of the text in its objective meaning, and, on the other hand, of the subjective comprehension of that meaning in the sense that the perpetrator knows ex ante what $\mathrm{c}$ onstitutes criminal conduct. When the courts interpret the statutory elements of a criminal offence and extract the abstract statutory definition of the criminal offence, they naturally interpret the statutory elements with regard to the concrete facts of the given case (i.e. the past event) that are relevant from the perspective of the abstract definition of the criminal offence - they namely interpret the statutory definition of the criminal offence with regard to the legally relevant facts of a concrete case."109

\subsubsection{Non-legal arguments}

In the selected decisions of the Slovenian Constitutional Court, the non-legal arguments were identified in 3 decisions where they were deployed 8 times in total. Albeit not as as a tool for interpreting the constitutional provisions but an argument in the subsumption process, a deployment of non-legal arguments (i.e., opinions of non-legal experts) is very well illustrated in the decision number U-I-83/20. Reviewing the constitutionality of the COVID-19 measures (i.e., the prohibition of movement outside the municipalities of one's residence), the Constitutional Court referred to the opinions of the government's expert group for COVID-19 and the National Institute of Public Health:

“/../ Nor is it irrelevant for the assessment of proportionality in a narrow sense that measures can be applied only in areas where the existence of risks can be established on the basis of existing expert information. If these areas are scattered throughout the country, they may also cover the entire country. As already mentioned, the epidemic was declared to be spread on the territory of the entire country precisely in view of the epidemiological situation as established by the National Institute of Public Health."110 
Table 1: Frequency of methods of interpretation in the selected case law of the Constitutional Court

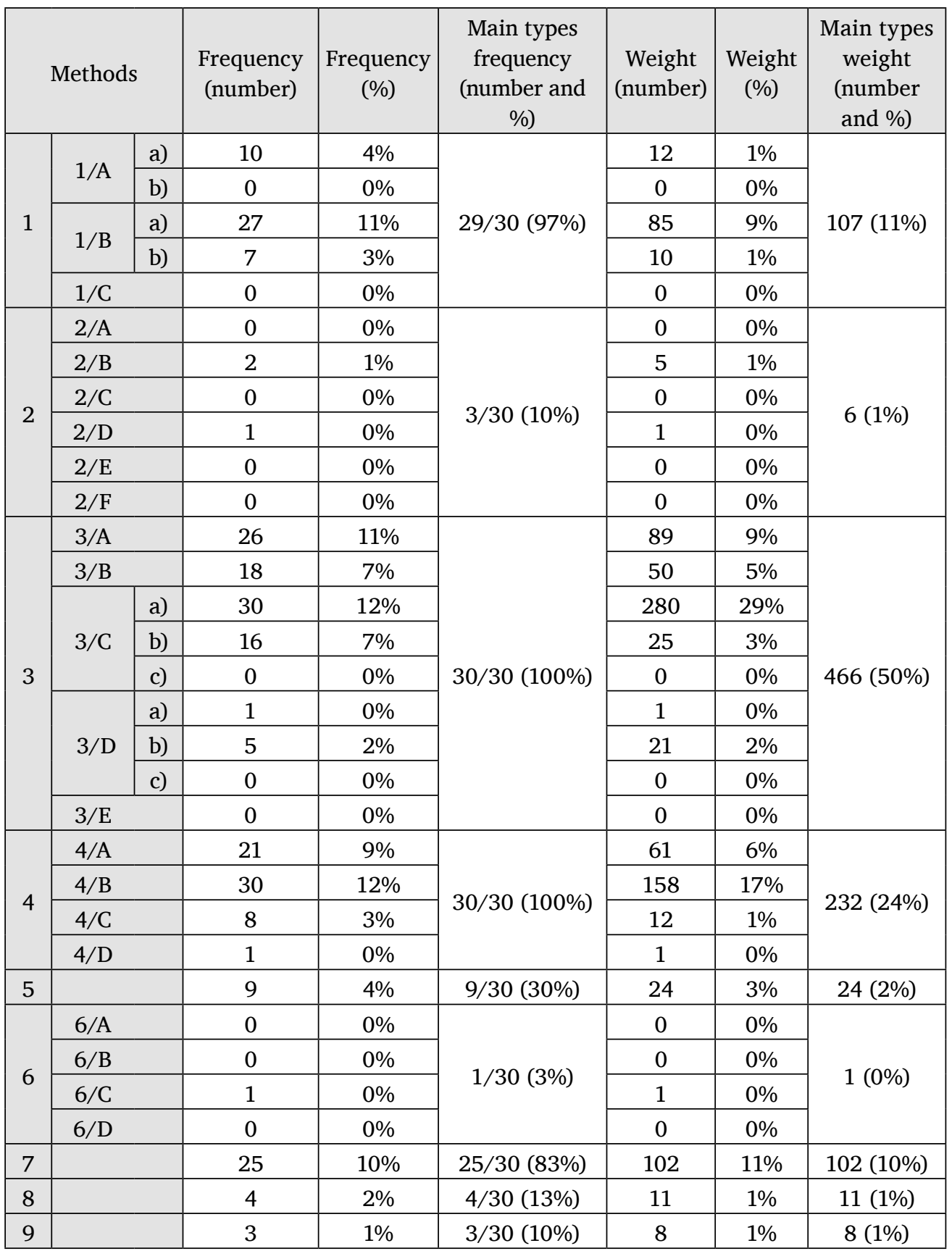




\section{Legend:}

1. Grammatical (textual) interpretation

$1 / A$. Interpretation based on ordinary meaning

a) Semantic interpretation

b) Syntactic interpretation

1/B. Legal professional (dogmatic/doctrinal) interpretation:

a) Simple conceptual dogmatic/doctrinal interpretation

b) Interpretation on the basis of legal principles

$1 /$ C. Other professional interpretation

2. Logical (linguistic-logical) arguments

2/A. Argumentum a minore ad maius

$2 / B$. Argumentum a maiore ad minus

$2 / C$. Argumentum ad absurdum

2/D. Argumentum a contrario / arguments from silence

$2 / E$. Argumentum a simili and, within it, analogy

$2 / F$. Interpretation according to other logical maxims

3. Domestic systemic arguments

3/A. Contextual interpretation, in a narrow and broad sense

$3 / B$. Interpretation of constitutional norms on the basis of domestic staturory law

$3 / C$. Interpretation of the constitution on the basis of case law of the Constitutional Court

a) References to specific previous decisions of the Constitutional Court (as "precedents")

b) References to the "practice" of the Constitutional Court

c) References to abstract norms formed by the Constitutional Court (e.g., the rules of procedure)

$3 / D$. Interpretation of the Constitution on the basis of the case law of ordinary courts

a) Interpretation referring to the practice of ordinary courts (not of single case decisions)

b) Interpretation referring to individual court decisions (as "precedents" in the judiciary)

c) Interpretation referring to abstract judicial norms (directives, principled rulings, law unification decisions, etc.)

3/E. Interpretation of constitutional provisions and fundamental rights on the basis of normative acts of other domestic state organs

4. External systemic and comparative law arguments:

4/A. Interpretation of fundamental rights on the basis of international treaties

$4 / B$. Interpretation of fundamental rights on the basis of individual case decisions or case law ('judicial' practice) of international fora.

4/C. Comparative law arguments: e.g., references to norms or case decisions of a particular foreign legal system

$4 / D$. Other external sources of interpretation (e.g., customary international law, ius cogens, etc.)

5. Teleological / objective teleological interpretation

6. Historical / subjective teleological interpretation (based on the intention of the

constitution-maker):

6/A. Interpretation based on ministerial / proposer justification

6/B. Interpretation based on draft material: references to travaux préparatoires / Materialen / and

legislative history

6/C. In general, references to the intention, will etc. of the constitution-maker

$6 / D$. Other reasons based on the circumstances of making or modifying/amending the constitution or the constitutional provision in question

7. Arguments based on jurisprudence / scholarly works

8. Interpretation in light of general legal principles

9. Substantive interpretation / non-legal arguments

Frequency (number): Number of decisions in which a method appears

Main types frequency: Number of decisions in which main methods appear through their sub-types

Weight (number): Total number of occurrences of a method within a decision

Weight (\%): Total number of occurrences of a method in \%

Main types weight (number and \%): Total number and \% of occurrences of main methods through

their sub-types 


\subsection{Decisive methods}

Our survey revealed that it is often difficult to distinguish between arguments that have decisively contributed to a particular substantive decision of the Constitutional Court and those for which this cannot be said. Where the matter is more or less clear, in some cases there is only one argument that in itself and without other arguments has led to the given conclusion on the merits as the decisive argument, while in other cases there are several decisive arguments in the Constitutional Court's decisions. Additionally, the analyses of the selected case law discerned that in certain decisions decisive arguments are used in more than one occasion (i.e., they were deployed in the same decision in multiple occasions).

Most importantly, we found that in our sample of case law a simple conceptual dogmatic interpretation as a type of the legal professional (dogmatic) interpretation was most often used as a decisive method of interpretation. The Constitutional Court uses a special legal meaning of words that is uniformly accepted and recognized by lawyers as the decisive interpretative tool in 24 decisions from our sample of case law and was deployed 32 times in aggregate, which amounts to $46 \%$ of all identified instances of deployment of decisive arguments (see Table $2,1 / \mathrm{B} / \mathrm{a})$. Other types of grammatical (textual) interpretation such as interpretation based on ordinary meaning and other professional interpretation, however, were not used as methods which in themselves and without other arguments would have led to the given conclusion/decision of the Constitutional Court.

Frequently used as a decisive method is also the contextual interpretation in a broad sense. By deploying this argument, the Constitutional Court makes reference to the place of the constitutional provision to be interpreted in the Constitution. As noted in subsection 2.2.3, this domestic systemic argument is deployed in a broad sense when a constitutional court determines the meaning of a given constitutional provision with respect to other specific constitutional provisions by referring to fundamental rights stipulated in the constitution or to other constitutional provisions. We found that in our sample od case law this interpretative tool is contained as a decisive method in 13 decisions and was deployed 17 times altogether, which amounts to $24 \%$ of all identified instances of deployment of decisive arguments (see Table 2, 3A).

In the decision number U-I-40/12, for example, the Constitutional Court deployed both methods of interpretation that are most frequently used as decisive ones, namely a simple conceptual dogmatic interpretation and a contextual interpretation in a narrow and/or broad sense. In this case, the Supreme Court of the Republic of Slovenia filed a request to review the constitutionality of several provisions of the Prevention of Restriction of Competition Act (PRCA-1). The Constitutional Court ruled that the first sentence of the first paragraph of Article 28 of the PRCA-1 is inconsistent with the Constitution. Additionally, the Court held that 
the National Assembly must remedy the unconstitutionality within one year and that several other provisions of the same act are not inconsistent with the Constitution. In the reasoning of the decision, the Constitutional Court stated inter alia that in the case at hand the decisive legal circumstance is that the first paragraph of Article 28 of the PRCA-1 determines that the measures which interfere with the spatial privacy of companies are ordered by the Slovenian Competition Protection Agency, not a court, including when such measures are ordered and executed against the will of legal entities. This is, according to the Constitutional Court, inconsistent with the requirement under the second paragraph of Article 36 of the Constitution, which requires a prior court order in such instances. When exercising these authorisations, the Agency will - by the nature of the matter and with regard to the degree of their invasiveness, which allows the Agency to conduct a complete search of business premises and the objects thereon - also interfere with the narrower circle of the spatial privacy of the legal entity. Therefore, according to the Constitutional Court, it is necessary to concur with the applicant (e.g. the Supreme Court) that the challenged provision inadmissibly limits the constitutional right determined by the first paragraph of Article 36 of the Constitution and is thus inconsistent therewith. ${ }^{111}$ - In this case, the Constitutional Court deploys two arguments as the decisive arguments for its decision that the first sentence of the first paragraph of Article 28 of the PRCA- 1 is inconsistent with the Constitution: Firstly, it uses the simple conceptual dogmatic interpretation as a form of legal professional (dogmatic) interpretation. By deploying this method of interpretation, the Constitutional Court uses a special legal meaning of words that is uniformly accepted and recognized by lawyers. Secondly, the Constitutional Court deploys a contextual interpretation in a narrow sense by exploring the meaning of a constitutional norm on the basis of its point, which follows from its place in the system of legal norms. Here the meaning of the fundamental, right, which is stipulated in Article 36 of the Constitution (e.g. the right to spatial privacy and inviolability of dwellings), is determined without comparing it with other specific constitutional provision.

In our sample of case law, other methods of interpretation than those mentioned above appear as the decisive ones significantly less frequently. There are individual types and groups of arguments and methods that do not appear as the decisive ones at all. Among these are the historical interpretation and teleological interpretation as well as logical arguments. Last but not least, in this segment of the research our survey revealed that all types of methods of interpretation that are used by the Constitutional Court were deployed, more or less often, to support the Constitutional Court's substantive decisions, either as defining or strengthening arguments or as mere illustrations with marginal significance. 
Table 2: Decisive arguments and methods of interpretation

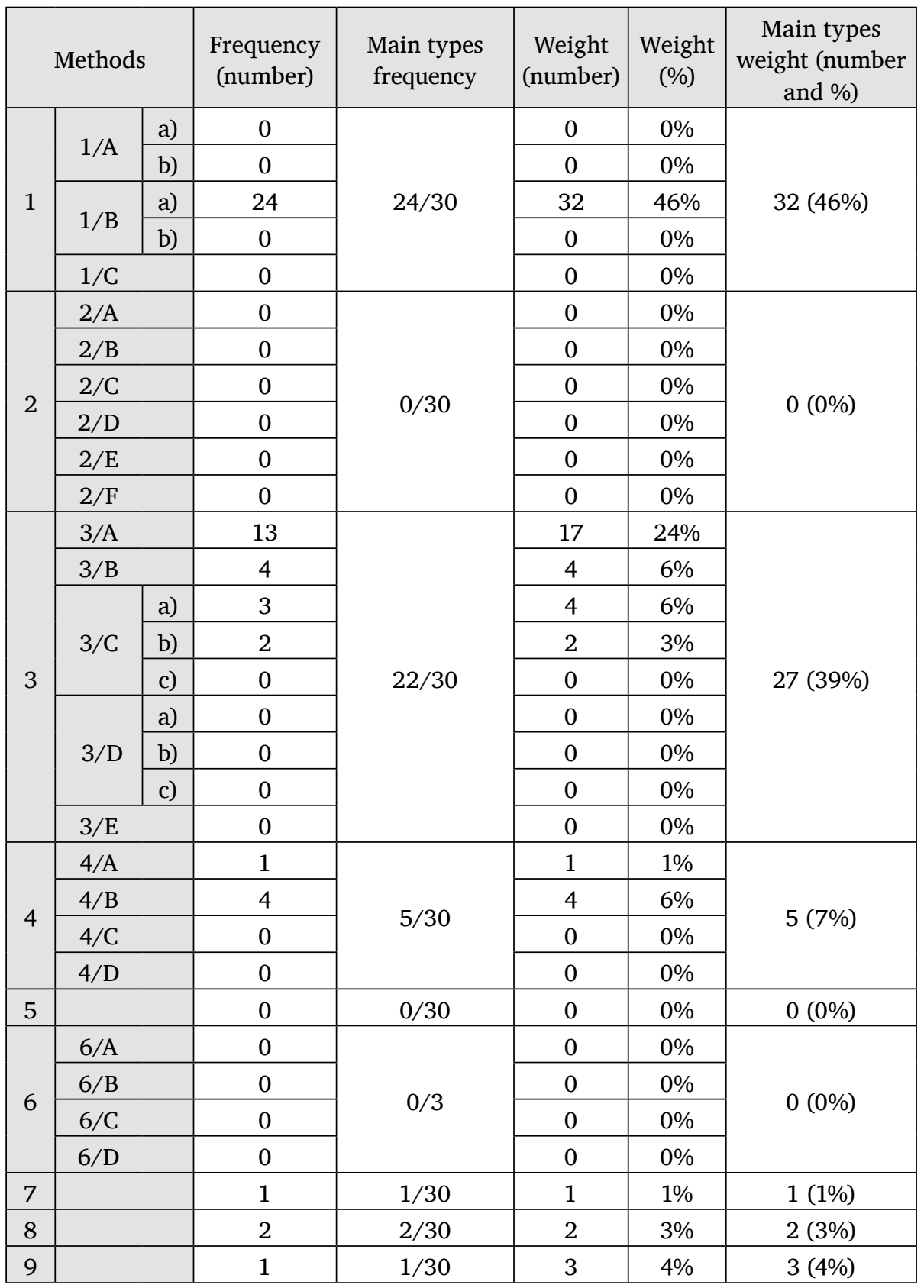

Legend: See Table 1 


\subsection{Conclusion}

The study revealed that, when reasoning its decisions and determining the meaning of the constitution in cases regarding fundamental rights, the Constitutional Court uses and combines a wide range of different methods of legal interpretation. In our sample of the Constitutional Court's decisions, domestic systemic arguments are the most frequently used method of interpretation. In our sample of case law, they have been deployed in $50 \%$ of all identified instances of deployment of main types of methods. Among them, the most frequently deployed type was the interpretation on the basis of case law of the Constitutional Court, and regarding this method of interpretation, the most frequently used are references to specific previous decisions of the Constitutional Court as precedents. This interpretative tool was also found in all 30 decisions from our sample and has been deployed in $28 \%$ of all identified instances of deployment of interpretative methods and arguments. The frequency and weigh of other types of domestic systemic arguments and methods of constitutional interpretation is significantly smaller.

The second most commonly used main type interpretative method in the judicial practice of the Slovenian Constitutional Court are external systemic and comparative law arguments. This group of arguments has been deployed in $24 \%$ of all identified instances of deployment of arguments and methods. However, not all types of external and comparative law arguments are used with equal frequency and they do not hold equal weigh in the interpretative practice of the Slovenian Constitutional Court. The most frequently deployed type is the interpretation of fundamental rights on the basis of judicial practice of international courts. Understandably, this method is present in all decisions from our sample of case law as references to the ECtHR or ECJ judgements have been among the criteria for the selection of Constitutional Court's cases. In overall, it was deployed in $16 \%$ of all identified instances of deployment of arguments and methods. $81 \%$ of all references to judicial practice of international courts were made to individual case decisions of the ECtHR and 19 $\%$ of references were made to the case law of the ECJ. The Constitutional Court made no reference to judicial practice of other international courts. Among other external systemic arguments, the interpretation of fundamental rights on the basis of international treaties amounts to $6 \%$ and the comparative law arguments to less than $1 \%$ of all identified instances of deployment of arguments and methods of interpretation.

The third most frequently used interpretative arguments are those based on scholarly works. In the selected decisions of the Constitutional Court, this interpretative method was deployed in $10 \%$ of all identified instances of deployment of arguments and methods. While the largest share of references (52\%) were made to the scientific monographs, the Constitutional Court also made references to the scientific articles (22\%) and to the commentaries (26\%).

A method of interpretation quite frequently used in the Slovenian constitutional judicial practice is also the grammatical (textual) interpretation. It was deployed in 
$11 \%$ of all identified instances of deployment of main type arguments and methods. Among different forms and types of grammatical interpretation, the Constitutional Court resorted most of ten to the interpretation based on ordinary meaning and legal professional (dogmatic) interpretation. As a form of legal professional (dogmatic) interpretation, a simple conceptual dogmatic interpretation of the Constitution takes place in $9 \%$ of all identified instances of deployment of arguments.

The review discerned that in our sample of case law certain methods of constitutional interpretation and their (sub)types took place in only $1 \%$ (or less) of all identified instances of deployment of methods and arguments. Those are the interpretation based on ordinary meaning which is a type of grammatical (textual) interpretation, historical interpretation and interpretation in light of general legal principles. Less common are/is also logical arguments, teleological interpretation and substantive interpretation (non-legal arguments).

Our study also revealed that regarding international treaties in the selected decisions most references were made to the European Convention on Human Rights, while significantly less frequently the Constitutional Court referred to the Charter of Fundamental Rights of the European Union. When deploying logical arguments, the Constitutional Court used in several occasions argumentum a maiore ad minus and argumentum a contrario. Regarding teleological interpretation, we found that, usually, it is fused with other methods of interpretation and it is sometimes difficult to distinguish it from other tools of constitutional interpretation. In our review, we searched tor instances where the Constitutional Court refers, either explicitly or implicitly, to the purpose of the Constitution and its individual provisions.

Furthermore, our survey revealed that in our sample of case law a simple conceptual dogmatic interpretation as a type of legal professional (dogmatic) interpretation was most often used as a decisive interpretative method. Also, frequently used as a decisive method is the contextual interpretation in a broad sense. In our sample of case law, other methods of interpretation appear as the decisive ones significantly less frequently. Last but not least, there are individual main types methods or groups of arguments that do not appear as the decisive ones at all. Among these are historical interpretation and teleological interpretation as well as logical arguments.

\section{On the Interpretation of Fundamental Rights in the Case Law of the European Court of Human Rights}

\subsection{General Remarks On the Selected Judgements of the ECtHR (and ECJ)}

We will now proceed with analysing 28 cases of the ECtHR and 2 cases of the ECJ referenced by the Slovenian Constitutional Court. A more detailed analysis of 
individual cases will be focused on the more recent ones. The selected decisions of both international courts were considered on the merits in the decisions of Constitutional Court which were included in our study. In studying the selected decisions of the Constitutional Court on the one hand, and the ECtHR and ECJ case law on the other, we will use more or less the same methodology, but will have to adjust its application due to the differences between the two courts in their style of adjudication. Above all, in the subsection on methods of interpretation, a substantive/ qualitative analyses of the selected case law of the ECtHR (and ECJ) will predominate. In other words, the statistical/quantitative analyses will not be as "plastic" as it was in the section on the methods used by the Slovenian Constitutional Court (i.e., regarding case law of the ECtHR and the ECJ, we will rely on a descriptive quantitative assessment). When referring to individual decisions/judgements, the style of our analyses will slightly differ from the one used in the section on the constitutional adjudication. Here, too, some adjustments seem sensible and necessary.

\subsection{Arguments and methods of interpretation}

Our analysis of the selected case law of the ECtHR and the ECJ revealed inter alia that, similarly to the Slovenian Constitutional Court, the Strasburg Court and the Luxemburg Court use a wide range of different interpretative methods and arguments when reasoning their decisions and determining the meaning of the rights stipulated in the Convention and the Charter. Both courts use certain interpretative methods more frequently than others. They often use a combination of different methods and arguments, while in some occasions it is difficult to distinguish between different methods and arguments used. Last but not least, the analyses also discerned that in our sample of the ECtHR and the ECJ case law some interpretative arguments and methods have proven to be more decisive than others.

\subsubsection{Grammatical (textual) interpretation}

The general impression is that, regarding different types of grammatical (textual) interpretation, the interpretation of the Convention based on an ordinary meaning of words was not used very frequently by the ECtHR. The use of semantic interpretation based on an ordinary meaning of words can be illustrated, for example, with the explanation of substance of the (right to) "liberty" as provided for in paragraph 1 Article 5 of the Convention, and the notion of impartiality in paragraph 1 Article 6 of the Convention. ${ }^{12}$ The semantic interpretation based on an

112 "In proclaiming the 'right to liberty', paragraph 1 of Article 5 (art. 5-1) is contemplating individual liberty in its classic sense, that is to say the physical liberty of the person." See Engel and others v. The Netherlands, § 58. See also Amuur v. France, § 42, and Guzzardi v. Italy, § 92. "The Court reiterates that impartiality normally denotes the absence of prejudice or bias and its existence or otherwise can be tested in various ways." See Morice v. France, § 73. 
ordinary meaning of words is traceable also in the decisions of the ECJ, for instance in the field of the right to protection of personal data in the Charter. ${ }^{113}$

The grammatical (textual) interpretation is sometimes expressly referred to. The Court, for example, describes "the wording" or the meaning of the "letter" of the relevant provision:

"The safeguards mentioned above are fundamental aspects of the right to a fair trial enshrined in Article 6 of the Convention. Neither the letter nor the spirit of Article 6 prevents a person from waiving them of his own free will, either expressly or tacitly."114

As in the sample of case law of the Constitutional Court, in the selected case law of the ECtHR and the ECJ too no syntactic interpretation has been identified.

However, it comes probably as no surprise that legal professional (dogmatic) interpretation is much more frequently used, both as a simple conceptual interpretation and as interpretation based on legal principles. The Court deployed a simple contextual interpretation by referring to a special legal meaning of words when determining their substance. For example, "the victim status of the applicant" for the purposes of the admissibility decision under the Convention cannot be interpreted with non-legal linguistic methods. Here, the word "victim" 115 is used as a special legal term that is much narrower than the generally accepted meaning. In contrast, the Court held that the notion of "home" in paragraph 1 Article 8 of the Convention is wider - a non-lawyer would probably not conceive it so broad at first sight. ${ }^{116}$

113 "In those circumstances, it must be considered that the right to respect for private life with regard to the processing of personal data, recognised by Articles 7 and 8 of the Charter, concerns any information relating to an identified or identifiable individual /.../" See Volker und Markus Schecke GbR and Hartmut Eifert v. Land Hessen, § 52. Since the paragraph 1 Article 8 of the Charter stipulates that "everyone has the right to the protection of personal data ...", the above cited interpretation of the ECJ can be understood as merely semantic, although it is also not completely foreign to the contextual interpretation.

114 See Scoppola v. Italy (no. 2), § 135. Another examples are: “The wording of Article $7 \S 1$, second sentence, indicates that the starting-point in any assessment of the existence of a penalty is whether the measure in question is imposed following conviction for a 'criminal offence'." Ibid, § 97; "Besides, the applicant's way of life at the time, as disclosed by the documentary evidence filed, is in no way consonant with the ordinary meaning of the word 'vagrant', this being the meaning that has to be utilised for Convention purposes. /.../ at the hearing of 9 February 1978 before the Commission, their Agent described Mr. Guzzardi as 'a vagrant in the wide sense of the term', 'a monied vagrant' /.../ In addition to vagrants, sub-paragraph (e) (art. 5-1-e) refers to persons of unsound mind, alcoholics and drug addicts." See Guzzardi v. Italy, § 98.

115 »When declaring the case admissible, the Court considered the question whether the applicant could claim to be a victim of the alleged breaches of the Convention.« See Roşca v. Moldova, § 18.

116 "The Court would point out that, as it has now repeatedly held, the notion of 'home' in Article $8 \S 1$ encompasses not only a private individual's home. It recalls that the word 'domicile' in the French version of Article 8 has a broader connotation than the word 'home' and may extend, for example, to a professional person's office." See Petri Sallinen and Others v. Finland, § 70. 
In the Court's reasoning of its decisions, specific legal meaning is attributed also to the words in other main articles of the Convention. For example, to "civil rights and obligations" and "criminal charge" in Article 6,117 and to the notion of "private life" and "family live" in the Article 8 of the Convention. ${ }^{118}$ The Court uses special legal terminology also when explaining the procedural aspects of the decision making. ${ }^{119}$ In some cases, a phrase regularly used by the Court contains the special meaning exclusively in a legal sense, such as "a minimum level of severity". ${ }^{20}$

The interpretation of the Convention based on the legal principles as developed in the case law of the ECtHR is quite common and can be found in most of the selected judgments of the Court. An example is the interpretation of the Article 10 of the Convention. The Court has established different principles governing its review in cases where the expression contains statements of fact and value judgments. ${ }^{121}$ Another example is the principle of impartiality of a tribunal in the light of Article 6 of the Convention, where the Court developed the subjective and objective test. ${ }^{122}$

In some cases, the Court uses legal principles to limit the scope of a right. Such is the case Neumeister $v$. Austria, where the principle of equality of arms is in the focus under Article 5 of the Convention. The reasoning contains a combination of legal interpretation based on legal principles and legal meaning of words. ${ }^{123}$ In general, the

117 See Engel and others v. The Netherlands, § 79.

118 See P.B. and J.S. v. Austria, § 26, 30.

119 "In determining whether substantial grounds have been shown for believing the existence of a real risk of treatment contrary to Article 3 (art. 3) the Court will assess the issue in the light of all the material placed before it or, if necessary, material obtained proprio motu ..." See Vilvarajah and Others v. the United Kingdom, $\S 107$. "The Court notes that the application is not manifestly ill-founded within the meaning of Article $35 \S 3$ of the Convention. It further notes that it is not inadmissible on any other grounds. It must therefore be declared admissible." See Novaya Gazeta V Voronezhe v. Russia, § 32 .

120 See Vilvarajah and Others v. the United Kingdom, § 107.

121 "In its practice, the Court has distinguished between statements of fact and value judgments. While the existence of facts can be demonstrated, the truth of value judgments is not susceptible of proof. The requirement to prove the truth of a value judgment is impossible to fulfil and infringes freedom of opinion itself, which is a fundamental part of the right secured by Article 10 (see Lingens v. Austria, 8 July 1986, § 46, Series A no. 103)." See Novaya Gazeta V Voronezhe v. Russia, § 37.

122 "According to the Court's constant case-law, when the impartiality of a tribunal for the purposes of Article $6 \S 1$ is being determined, regard must be had to the personal conviction and behaviour of a particular judge in a given case - the subjective approach - as well as to whether it afforded sufficient guarantees to exclude any legitimate doubt in this respect - the objective approach ..." See Švarc and Kavnik v. Slovenia, § 37.

123 "Nor is it possible to justify application of the principle of 'equality of arms' to proceedings against detention on remand by invoking Article 5 (4) (art. 5-4) which, while requiring that such proceedings shall be allowed, stipulates that they should be taken before a 'court'. This term implies only that the authority called upon to decide thereon must possess a judicial character, that is to say, be independent both of the executive and of the parties to the case; it in no way relates to the procedure to be followed. In addition, the provision in question also lays down that such remedies must be determined 'speedily' (the French text uses the somewhat less expressive term 'à bref délai'). /.../ Full written proceedings or an oral hearing of the parties in the examination of such remedies would be a source of delay which it is important to avoid in this field." See Neumeister v. Austria, § 24. 
Court recognizes the principle of equality of arms as a right stemming out of Article 6 of the Convention and associates it with the principles of adversarial procedure and fair trial. ${ }^{124}$ This is an example how the Court interprets the Convention by contextualizing various legal principles.

Even more common, almost omnipresent example of interpretation based on legal principles is the principle of proportionality, which governs the review in cases where the interference with a right has been recognized to be prescribed by law and it follows a legitimate aim. The test of necessity in a democratic society, a pressing social need, and the proportionality of the interference in comparison to the legitimate aim pursued, are undoubtedly the expression of the principle of proportionality, as developed by the ECtHR. ${ }^{125}$ Similarly, the positive obligations of the state stem out of the well-developed and often reiterated Convention principle that the rights must be effective in practice and not theoretical and illusory. ${ }^{126}$

In some cases, the difference between simple legal doctrinal interpretation and interpretation on the basis of legal principles is not evident prima vista. For instance, the phrase "margin of appreciation" 127 could be interpreted as a combination of words that have special legal meaning in the framework of the ECtHR case law. However, through tens and hundreds of the ECtHR decisions and judgments through decades the concept now includes a variety of general criteria and can be understood as a special legal principle under the Convention with significant importance. It has evolved as one of fundamental principles of interpretation for determining the level of stringency of review that has to be adopted by the Court regarding individual issues at hand. ${ }^{128}$ Similar status could be ascribed to phrases "protected by law" and "in accordance with law", often reiterated in the Convention. The meaning of the latter, for example, exceeds the mere legal subsumption of the concrete state action to the law in question and, as a principle, requires also certain quality of such law. ${ }^{129}$

124 "The Court reiterates that the principle of equality of arms is only one feature of the wider concept of a fair trial, which also includes the fundamental right that proceedings should be adversarial ..." See Salov v. Ukraine, § 87.

125 See for example Novaya Gazeta V Voronezhe v. Russia, § 34; Buck v. Germany, § 44.

126 See for instance Scoppola v. Italy (no. 2), § 104.

127 »The Contracting States have a certain margin of appreciation in assessing whether such a need exists, but it goes hand in hand with European supervision, embracing both the legislation and the decisions applying it, even those given by an independent court." See Vajnai v. Hungary, § 43. See also Benediktsdóttir v. Iceland, (ii) Application of these principles.

128 See for example Arai, Yutaka: The margin of appreciation doctrine and the principle of proportionality in the jurisprudence of the ECHR, Intersentia, Antwerp, Oxford 2002.

129 "The expression 'in accordance with the law' in paragraph 2 of Article 8 (art. 8-2) requires, to begin with, that the interference must have some basis in domestic law. Compliance with domestic law, however, does not suffice: the law in question must be accessible to the individual concerned and its consequences for him must also be foreseeable ..." See Leander v. Sweden, § 50. See also Niedbała v. Poland, § 79. 
The Court resorts to the interpretation with the help of legal principles not only when interpreting material aspects of the Convention but also procedural as often procedural norms can be found indefinite and inexhaustible as well. An example of "procedural" legal principle is the ratione temporis principle, which determines the jurisdiction of the ECtHR. ${ }^{130}$

Significantly less common type of grammatical (textual) interpretation is nonlegal professional interpretation. In the selected case law of the ECtHR, it has not occurred in the framework of direct interpretation of the text of the Convention (as a tool for determining the upper premise of judicial syllogism), but rather in the contextual interpretation or as part of legal subsumption. ${ }^{131}$

\subsubsection{Logical arguments}

The analyses of our sample of the ECtHR's case law revealed that the Court used the following two types of logical arguments for the interpretation of the Convention: argumentum ad absurdum and argumentum a contrario. Other logical arguments are not non-existent in the case law of the Court, however, as it will be briefly presented, they are rather applied in the process of subsumption (and not interpretation of the Convention itself).

Argumentum ad absurdum has been most often applied in order to demonstrate that certain hypothetical interpretation, if adopted or recognized by the Court, would lead to the untenable, unacceptable results. Examples can be found in cases

130 »The problem of determining the limits of its jurisdiction ratione temporis in situations where the facts relied on in the application fell partly within and partly outside the relevant period has been most exhaustively addressed by the Court in the case of Blečić $v$. Croatia /.../. In that case the Court confirmed that its temporal jurisdiction was to be determined in relation to the facts constitutive of the alleged interference /.../". See Šilih v. Slovenia, § 146.

131 For instance, regarding the consequences of sexual abuse, the Court noted: "For the Court, States have a positive obligation inherent in Article 8 of the Convention to criminalise offences against the person, including attempted offences, and to reinforce the deterrent effect of criminalisation by applying criminal law provisions in practice through effective investigation and prosecution /.../. Where the physical and moral welfare of a child is threatened, such injunction assumes even greater importance. The Court notes in this connection that sexual abuse is unquestionably an abhorrent type of wrongdoing, with debilitating effects on its victims. Children and other vulnerable individuals are entitled to State protection, in the form of effective deterrence, from such grave types of interference with essential aspects of their private lives /.../." See K.U. v. Finland, § 46. Although this is a generally known and accepted position, the "debilitating effects" of sexual abuse on victims are primarily subject of other (non-legal) professions. Another example is the interpretation of the Court related to the medical issues: "Lastly, apart from the concern for the respect of the rights inherent in Article 2 of the Convention in each individual case, more general considerations also call for a prompt examination of cases concerning death in a hospital setting. Knowledge of the facts and of possible errors committed in the course of medical care are essential to enable the institutions concerned and medical staff to remedy the potential deficiencies and prevent similar errors. The prompt examination of such cases is therefore important for the safety of users of all health services /.../ See Šilih v. Slovenia, § 196. The methods used to remedy the medical deficiencies are certainly not part of legal profession. 
Salov v. Ukraine $e^{132}$ and Engel and others v. the Netherlands. ${ }^{133}$ In the former case, the Court explains why Article 10 should be read in a way that it does not prohibit a certain type of expression - this is therefore an argument which elaborates the scope of a right under Article 10. If the former case widens the scope of a right by applying the ad absurdum argument, the latter case presents its application in function of narrowing the scope of a Convention right. The reasoning (see the footnotes) transparently displays the ad absurdum logic of interpretation. Last but not least, where the Court does not show explicitly to which unacceptable results would lead an undesired interpretation of the Convention, an implicit, milder form of this logical argument has been identified. ${ }^{134}$

Argumentum a contrario is identifiable for instance in cases where the Court emphasizes that the Convention does not offer the protection of a certain right since it is not written in the text itself. The legal consequences, which follow from the specific provisions of the Convention, are therefore not applicable to a situation or a right, demanded by the applicant. The ECtHR held:

"In addition, neither the Convention nor its Protocols confer the right to political asylum /.../."135

"Unlike most of the substantive clauses of the Convention and of Protocols Nos. 1 and 4, Article 3 makes no provision for exceptions and no derogation from it is permissible under Article 15, even in the event of a public emergency threatening the life of the nation /.../.".136

"\%... but the list of deprivations of liberty set out therein is exhaustive, as is shown by the words 'save in the following cases'. A disciplinary penalty or measure may in consequence constitute a breach of Article 5 para. 1 (art. 5-1).”137

132 "Furthermore, Article 10 of the Convention as such does not prohibit discussion or dissemination of information received even if it is strongly suspected that this information might not be truthful. To suggest otherwise would deprive persons of the right to express their views and opinions about statements made in the mass media and would thus place an unreasonable restriction on the freedom of expression set forth in Article 10 of the Convention." See Salov v. Ukraine, § 113.

133 "The Court considers that the words 'secure the fulfilment of any obligation prescribed by law' concern only cases where the law permits the detention of a person to compel him to fulfil a specific and concrete obligation which he has until then failed to satisfy. A wide interpretation would entail consequences incompatible with the notion of the rule of law from which the whole Convention draws its inspiration /.../. It would justify, for example, administrative internment meant to compel a citizen to discharge, in relation to any point whatever, his general duty of obedience to the law." See Engel and others v. The Netherlands, § 69.

134 "Moreover, /.../ case-law, as one of the sources of the law, necessarily contributes to the gradual development of the criminal law /.../. Article 7 of the Convention cannot be read as outlawing the gradual clarification of the rules of criminal liability through judicial interpretation from case to case, provided that the resultant development is consistent with the essence of the offence and could reasonably be foreseen /.../" See Scoppola v. Italy (No. 2), § 101.

135 See Saadi v. Italy, § 124.

136 See Saadi v. Italy, § 127.

137 See Engel and others v. The Netherlands, § 57. 
In the following example from the case of Scoppola $v$. Italy, the Court emphasizes that in the sphere of criminal law the extensive interpretation should not be adopted. The silence of a law therefore dictates the interpretation with argumentum a contrario:

"Article $7 \S 1$ of the Convention goes beyond prohibition of the retrospective application of criminal law to the detriment of the accused. /.../ While it prohibits in particular extending the scope of existing offences to acts which previously were not criminal offences, it also lays down the principle that the criminal law must not be extensively construed to an accused's detriment, for instance by analogy /.../."138

This interpretation could be attributed to the subsumption process as it affects the interpretation of domestic criminal law. However, it at the same time determines the scope and strictness of review under Article 7. It is possible to deduce that in this manner this reasoning contains also an interpretation of the Convention itself.

From the above-cited cases it can be seen that the ad absurdum and a contrario arguments can be important and influential interpretative tools. The Court relies to them when determining the very frontiers and substantial limits of individual rights guaranteed under the Convention. These reasonings have far fetching and often general (erga omnes) consequences since the Court determines the material scope of protection it offers when interpreting the Convention.

Other identified examples of reasoning with logical arguments were found in the subsumption part of decisions (and not where the Convention itself is being interpreted). Argumentum a minore ad maius, for example, has been deployed at least implicitly; ${ }^{139}$ For the case law of the courts which widely refer to their previous decisions (precedents), it is almost inevitable to frequently depend on the interpretation with argumentum a simili. This argument functions in both directions: it can rely upon relevant similarities and thus seek the same legal consequence (analogy) or it can point out the relevant differences and therefore demand also the different treatment (distinguishing); ${ }^{140}$ the Court has for instance dismissed the arguments put forward in the case in hand on the grounds that

138 See Scoppola v. Italy (No. 2), § 93.

139 "The Court would emphasise that search and seizure represent a serious interference with private life, home and correspondence and must accordingly be based on a "law" that is particularly precise." See Petri Sallinen and Others v. Finland, § 90.

140 The Court, for example, has stated: "The Court considers that the present application is to be distinguished from those relied on by the Government. It observes, particularly in Garaudy and Lehideux and Isorni (both cited above), that the justification of Nazi-like politics was at stake. Consequently, the finding of an abuse under Article 17 lay in the fact that Article 10 had been relied on by groups with totalitarian motives." See See Vajnai v. Hungary, § 24. Or: "For the reasons stated in its judgment in Blečić /.../ and noting that there is nothing that would lead it to reach a different conclusion in the present case, the Court finds that the Government are not precluded from raising the ratione temporis objection at this stage of the proceedings /.../." See Šilih v. Slovenia, § 139. 
similar arguments have already been rejected in previous decision or judgment; ${ }^{141}$ However, in some cases differentiation between reasoning with mere subsumption and with interpretation of the Convention is an uneasy task. Such is the case where the Court states that specific Convention requirement is stricter in specific legal areas; ${ }^{142}$ The a simili argument can be found also in the selected ECJ judgments. The ECJ has evaluate the different degree of seriousness of the breach of the right to protection of personal data when legal persons and natural persons are concerned. ${ }^{143}$

Interestingly, the reasoning with argumentum a maiore ad minus has not been identified not as a part of judicial subsumption nor as a part of interpretation of Convention. In addition, in some cases, the Court explicitly resorts to "logic" when interpreting the provision of the Convention. ${ }^{144}$

\subsubsection{Systemic arguments}

Different types and forms of systemic arguments are deployed very frequently and can be found in almost every selected judgment of the ECtHR. Analysing our sample of the Court's case law, we found that in the majority of cases it uses contextual interpretation either in a narrow or broad sense and that in some cases, it also uses a "derogatory formulae".

Similar to the constitutional interpretation, the contextual interpretation of the Convention in a broad sense is deployed, for example, when the Court refers to other Convention provisions and compares them with the ones that are being interpreted in the first place. This may include references to substantive or procedural articles of Convention. The Court may compare the meaning of specific words in the provisions

141 See Saadi v. Italy, § 141.

142 In the part of the judgment, where the general principles on the requirement win accordance with law« are presented, the Court held: »Compliance with domestic law, however, does not suffice: the law in question must be accessible to the individual concerned and its consequences for him must also be foreseeable /.../. However, the requirement of foreseeability in the special context of secret controls of staff in sectors affecting national security cannot be the same as in many other fields. $/ \ldots /$ « See Leander v. Sweden, § 50, 51.

143, ,.../ the obligation to publish which follows from the provisions of the European Union rules the validity of which has here been brought into question does not go beyond the limits imposed by compliance with the principle of proportionality. The seriousness of the breach of the right to protection of personal data manifests itself in different ways for, on the one hand, legal persons and, on the other, natural persons. It is necessary to point out in this regard that legal persons are already subject to a more onerous obligation in respect of the publication of data relating to them." See Volker und Markus Schecke GbR and Hartmut Eifert v. Land Hessen, § 87.

144 "The Convention is to be read as a whole and therefore, as the Commission recalled in its report, any interpretation of Article 13 (art. 13) must be in harmony with the logic of the Convention." See Leander v. Sweden, § 78. This argument could be in substance related to systemic arguments. 
or, for instance, the structure of limitation/derogation clauses of various articles of the Convention. ${ }^{145}$

Contextual interpretation in a narrow sense of a specific Convention right often relates to the right's traditional and generally recognized structure, concept and function - at least as far as the main framework is concerned. Consequently, the differentiation between teleological and contextual interpretation in a narrow sense may be unclear since the concept of a right and intention behind it is usually highly correlated. Both interpretations (besides others) are used to gradually develop the case law, which gives the full substance and meaning to the fundamental rights and individual Convention provisions. Initially abstract and vague, the provisions of the Convention through time become materially concretized, specified and "filled in" (similar relates to interpreting constitutions). ${ }^{146}$ Among contextual interpretation in narrow sense is, for instance, reasoning with setting the criteria of review under the certain article of the Convention, ${ }^{147}$ setting the substantial characteristics of certain Convention right or a specific aspect of it, ${ }^{148}$ or just ensuring the minimal standards under certain provision (e.g. right) in the Convention. ${ }^{149}$

As special form of contextual interpretation, s "derogatory formulae" has been applied in our sample of case law where the Court denied applicability of lex posterior derogat legi priori rule in the specific legal field. ${ }^{150}$

145 "In the Court's opinion, comparison of Article 5 par. 1 (a) (art. 5-1-a) with Articles 6 par. 2 and 7 par. 1 (art. 6-2, art. 7-1) shows that for Convention purposes there cannot be a 'condamnation' (in the English text: 'conviction') unless it has been established in accordance with the law that there has been an offence - either criminal or, if appropriate, disciplinary /.../." See Guzzardi v. Italy, § 100. "Unlike most of the substantive clauses of the Convention and of Protocols Nos. 1 and 4, Article 3 makes no provision for exceptions and no derogation from it is permissible under Article 15, even in the event of a public emergency threatening the life of the nation /.../." See Saadi v. Italy, § 127.

146 Pavčnik, 2000, p.

147 "The Court reiterates that the reasonableness of the length of proceedings must be assessed in the light of the circumstances of the case and with reference to the following criteria: the complexity of the case, the conduct of the applicant and the relevant authorities and what was at stake for the applicant in the dispute /.../." See Švarc and Kavnik v. Slovenia, § 30.

148 "The Court observes that the right to freedom to receive information basically prohibits a Government from restricting a person from receiving information that others wish or may be willing to impart to him. Article 10 (art. 10) does not, in circumstances such as those of the present case, confer on the individual a right of access to a register containing information on his personal position, nor does it embody an obligation on the Government to impart such information to the individual." See Leander v. Sweden, § 74.

149 “/../ As the Court has stated on many occasions, Article $6 \S 1$ of the Convention does not compel the Contracting States to set up courts of appeal or of cassation, but a State which does institute such courts is required to ensure that persons having access to the law enjoy before such courts the fundamental guarantees in Article $6 / \ldots /$, and this unquestionably includes the requirement that the court must be impartial." See Morice v. France, § 88.

150 ".../ The Court notes that the obligation to apply, from among several criminal laws, the one whose provisions are the most favourable to the accused is a clarification of the rules on the succession of criminal laws, which is in accord with another essential element of Article 7, namely the foreseeability of penalties." See Scoppola v. Italy (no. 2), § 108. 
Another type of systemic arguments which can be used when the ECtHR interprets the Convention are references to the law of the member states, e.g. the (sub) statutory law and case law of regular courts of the member states against which in the case at hand a complaint has been lodged as well as of other member states. We found that this method has been deployed in our sample of case law of the ECtHR only in the framework of legal subsumption when the Court reviews the domestic legislation $^{151}$ and court decisions ${ }^{152}$ affecting the rights as guaranteed by the Convention. Regarding the latter, the Court, for instance, has also referred to the practice of the ordinary courts of member states via analysing the criteria they apply. ${ }^{153}$ This method of interpretation, however, has not been detected in those parts of reasoning where the Convention provisions themselves are being interpreted by the Court.

On the other hand, among the most frequently used systemic arguments is the method of interpretation on the basis of the ECtHR's case law which includes inter alia references to specific previous decisions of the Court as "precedents". In our sample of case law, every single judgment of the ECtHR includes several references to the previous case law of the Court. ${ }^{154}$ In the case of Morice v. France for example, the Court took the meaning of precedents to another level as it quoted (i.e., copied) the chosen paragraphs of the judgment's reasoning in full. ${ }^{155}$

The analysis of the case law from our sample also shows that the Court in some of these cases makes references - not to its specific previous decisions/judgements but to its own practice as such. ${ }^{156}$ However, in the judicial decision-making that recognizes the importance of precedents, it does not come as a surprise that the (non)departure from the established case law would be explicit:

"While the Court is not formally bound to follow any of its previous judgments, it is in the interests of legal certainty, foreseeability and equality before the law that it should not depart, without cogent reason, from precedents laid down in previous cases /.../p157

151 See for example Salov v. Ukraine, § 58, 96; Stubbings and others v. United Kingdom, § 52, 73.

152 ".../ The Court notes the comments of the UNHCR that, while the Dublin Convention may pursue laudable objectives, its effectiveness may be undermined in practice by the differing approaches adopted by Contracting States to the scope of protection offered. The English courts themselves have shown a similar concern in reviewing the decisions of the Secretary of State concerning the removal of asylum-seekers to allegedly safe third countries (see Relevant Domestic Law and Practice above, United Kingdom case-law)." See T. I. v. United Kingdom, p. 15. The emphasis added by the author.

153 "While it is true that there are limitations to the powers of the courts in judicial review proceedings (see paragraphs 89-92 above) the Court is of the opinion that these powers, exercisable as they are by the highest tribunals in the land, do provide an effective degree of control over the decisions of the administrative authorities in asylum cases and are sufficient to satisfy the requirements of Article 13 (art. 13)." See Vilvarajah and Others v. the United Kingdom, §126.

154 See for example Allan v. the United Kingdom, § 44.

155 See Morice v. France, § 124.

156 \%/../The Court has previously referred to the relevant international instruments, most notably the Data Protection Convention, in assessing data processing and protection practices in individual cases brought under Article 8 of the Convention." See Surikov v. Ukraine, § 74.

157 See Scoppola v. Italy (no. 2), § 104. 
"The Court does not see any reason to depart from its established case-law. /.../."158

The judgments of the ECtHR in some cases also include citations of the case law of constitutional court(s). However, among the selected case law, there are no examples where a reference to the concrete decision of a particular Constitutional court would amount directly to the interpretation of the Convention itself. These references too are rather included in the process of legal subsumption. ${ }^{159}$

As argued, the systemic arguments belong to the most frequently deployed methods of interpretation. However, references to abstract norms formed by the Court itself (for instance, Rules of Court of the EctHR) were not identified in our sample of the Court's case law. The same stands for the interpretation on the basis of other Council of Europe materials (i.e., those of Venice Commission and similar) as yet another form of systemic arguments as this method too appeared - not in the process of interpretation of the Convention itself but - as part of the subsumption (e.g. the assessment of the present case). ${ }^{160}$

In principle, arguments of systemic nature are also arguments of the Court regarding its position and competences and the scope of review adopted in a case under the consideration. ${ }^{161}$ The Court namely emanates from its international and subsidiary position, having in mind that it is not competent to conduct the review of constitutionality, but to check exclusively whether the domestic courts' reasoning in a particular case (dis)respects the requirements under the Convention. This reasoning determines the jurisdiction of the Court under the Convention and could be therefore regarded as a part of its interpretation in wider context.

The judicial review that is conducted systematically in specific order and steps, as the one regularly carried out by the Court, can also be understood as systemic arguments in material (substantial) sense. This kind of judicial review involves reasoning based on principles which are generally recognized under the Convention (i.e., they are not common just to one right) and stem out of the Convention system. Hereby various tests are taken into consideration, most notably the proportionality test. ${ }^{162}$

158 See Švarc and Kavnik v. Slovenia, § 16.

159 See for example Salov v. Ukraine, § 83; Surikov v. Ukraine, § 80.

160 \%/... The Court also takes note of /.../ the relevant resolutions of the Council of Judges of Ukraine which criticised the lack of financial and legislative guarantees for the functioning of the judicial bodies /.../." See Salov v. Ukraine, § 83. See also Leander v. Sweden, § 82.

161 "At the same time, the Court is not called upon to assess the quality of the applicable data protection framework in the abstract and must rather confine itself as far as possible to examining the particular consequences of application of its provisions in the case before it /.../" See Surikov v. Ukraine, § 81 .

162 "In addition to being lawful, the interference must also pursue a legitimate aim and be 'necessary in a democratic society'. In determining whether the impugned measures were 'necessary in a democratic society', the Court will consider whether, in the light of the case as a whole, the reasons adduced to justify them were relevant and sufficient and the measures were proportionate to the legitimate aims pursued /.../" See Surikov v. Ukraine, § 73. 
A specific example is a subjective and objective test of impartiality for the purposes of Article $6 \S 1$ of the Convention. ${ }^{163}$

\subsubsection{External systemic and comparative law arguments}

This group of interpretative arguments includes the interpretation of the Convention on the basis of other international treaties and on the basis of individual case decisions or case law ('judicial' practice) of other international or supranational courts, and other external sources of interpretation (e.g. customary international law, etc.).

Several examples of interpretation of fundamental rights from the Convention on the basis of other international treaties have been detected in the selected case law. ${ }^{164}$ Especially when the Court wants to change its course of interpretation, it often relies on the position of international law and consensus of member States. ${ }^{165}$ Such analysis is then used as a basis for dynamic interpretation of the relevant Convention provisions. ${ }^{166}$ Another example is:

"The Court considers that a long time has elapsed since the Commission gave the above-mentioned X v. Germany decision and that during that time there have been important developments internationally. In particular, apart from the entry into force

163 “/... According to the Court's settled case-law, the existence of impartiality for the purposes of Article $6 \S 1$ must be determined according to a subjective test where regard must be had to the personal conviction and behaviour of a particular judge, that is, whether the judge held any personal prejudice or bias in a given case; and also according to an objective test, that is to say by ascertaining whether the tribunal itself and, among other aspects, its composition, offered sufficient guarantees to exclude any legitimate doubt in respect of its impartiality /.../" See Morice v. France, § 73.

164 For example: "This is an established principle in the Court's case-law /.../ based on the general rule of international law embodied in Article 28 of the Vienna Convention /.../." See Šilih v. Slovenia, § 140. See also M. S. S. v. Belgium and Greece, § 251, where the Geneva Convention is considered in an asylum-seeker case.

165 In the case of P.B. and J.S. v. Austria the Court deployed comparative law arguments, i.e., references to norms of a particular foreign legal system, in this case of both the international and national legal systems: "The Court notes that since 2001, when the decision in Mata Estevez was given, a rapid evolution of social attitudes towards same-sex couples has taken place in many member States. Since then, a considerable number of member States have afforded legal recognition to same-sex couples (see above, paragraphs 27-30). Certain provisions of EU law also reflect a growing tendency to include same-sex couples in the notion of 'family' (see paragraph 26 above)." See P.B. and J.S. v. Austria, § 28, 29.

166 "To date, a certain level of consensus on the international level and, in particular, between the Council of Europe member States has been achieved as regards the fundamental data protection principles and the corresponding basic procedural safeguards to be included in the national legislative frameworks in order to justify the necessity of any possible interference. These principles were formulated in a number of treaties and other legal instruments, including the Council of Europe Data Protection Convention no. 108 and other documents /.../. At each stage, appropriate and adequate safeguards which reflect the principles elaborated in applicable data protection instruments must be put in place in order to justify the necessity of interference under Article 8 /.../." See Surikov v. Ukraine, $\S 74$. 
of the American Convention on Human Rights /.../, mention should be made of the proclamation of the European Union's Charter of Fundamental Rights. The wording of Article $49 \S 1$ of the Charter differs - and this can only be deliberate /.../ - from that of Article 7 of the Convention in that it states: /.../. Lastly, the applicability of the more lenient criminal law was set forth in the statute of the International Criminal Court and affirmed in the case-law of the ICTY /.../."167

Also, the ECJ's interpretation of the EU Law, i.e., the Charter, on the basis of other international treaty has been identified - namely on the basis of the Convention. The ECJ "returns the favor" to the ECtHR, so to speak, and cites its case law. ${ }^{168}$ In general, the effort of both Courts, the ECJ and ECtHR, to recognize each other's jurisprudence is clearly visible. The process of EU integration into the Convention system is one aspect and harmonized interpretation of the Convention and the relevant EU law is another. The latter is most likely a substantial precondition for the former and could be understood as a tool paving the way for making the integration possible.

However, the Court cites also the case law of other courts or tribunals. For example in Scoppola $v$. Italy and Šilih $v$. Slovenia, the Court interpreted Article 7 of the Convention with a reference to case law of the ICTY, ${ }^{169}$ the United Nations Human Rights Committee and Inter-American Court of Human Rights. ${ }^{170}$ Also, a reference to the generally recognised rules of international law has been detected in the procedural part of the decision - i.e., when interpreting the Article 35 of the Convention. ${ }^{171}$ When interpreting the Convention, the Court does on the other hand not refer only to the cogent law or law in the traditional sense. In several cases it interpreted

167 See Scoppola v. Italy (no. 2), § 105.

168 "Finally, according to Article $\neg 52(3)$ of the Charter, in so far as it contains rights which correspond to rights guaranteed by the Convention, the meaning and scope of those rights are to be the same as those laid down by the Convention. Article 53 of the Charter further states that nothing in the Charter is to be interpreted as restricting or adversely affecting the rights recognised inter alia by the Convention.” See Volker und Markus Schecke GbR and Hartmut Eifert v. Land Hessen, § 51. „The European Court of Human Rights has held on this point, with reference to the interpretation of Article 8 of the Convention, that the term 'private life' must not be interpreted restrictively and that 'there is no reason of principle to justify excluding activities of a professional ... nature from the notion of 'private life" (see, inter alia, Amann v. Switzerland, § 65, and Rotaru v. Romania, § 43)." Ibid., § 59.

169 "The Court considers that a long time has elapsed since the Commission gave the above-mentioned $\mathrm{X}$ v. Germany decision and that during that time there have been important developments internationally. /.../In the case of Berlusconi and Others, the Court of Justice of the European Communities, whose ruling was endorsed by the French Court of Cassation /.../, held that this principle formed part of the constitutional traditions common to the member States /.../ Lastly, the applicability of the more lenient criminal law was /.../ affirmed in the case-law of the ICTY /.../." See Scoppola v. Italy (no. 2), § 105.

170 "This approach finds support also in the jurisprudence of the United Nations Human Rights Committee and, in particular, of the Inter-American Court of Human Rights, /.../." See Šilih v. Slovenia, § 160.

171 ".../ In addition, according to the 'generally recognised rules of international law', there may be special circumstances which absolve applicants from the obligation to exhaust the domestic remedies at their disposal. See Scoppola v. Italy (no. 2), § 70. 
the Convention also with the reference to the soft law or the documents with the international policy character. ${ }^{172}$

\subsubsection{Teleological interpretation}

The analysis of the selected case law shows that the ECtHR uses the teleological interpretation quite often and in various manners. It may rely on its structural or procedural arrangement and its internationally and thus subsidiary position, where the general purpose of the procedure before the Court and the protection of human rights on the European level is in the centre of interpretation. This is important for example when the Court does not want to be too activist, too strict in the relation to the domestic courts' findings and their interpretation, ${ }^{173}$ or even depart from legal arguments and to decide upon the state's policy. ${ }^{174}$ This indeed influences the strictness of the ECtHR's scrutiny, which have direct effects for the level of stringency of the Convention's substantial requirements. ${ }^{175}$

An example where the Court interpreted the procedural aspects of the Convention with the teleological arguments is the following one:

"The Court reiterates that the purpose of the rule on exhaustion of domestic remedies is to afford the Contracting States the opportunity of preventing or putting right the violations alleged against them before those allegations are submitted to the Court $1 \ldots /$ In this way, it is an important aspect of the principle that the machinery of protection established by the Convention is subsidiary to the national systems safeguarding human rights /.../."176

However, the Court refers to the object and purpose of the Convention also when it interprets substantial provisions. Here are two examples of teleological reasoning when interpreting substantial rights under the Convention (teleological interpretation can be identified by phrases "essential element", "object and purpose", "the Court's task", etc.):

172 "Moreover, that conclusion is in line with points IV and XII of the guidelines of the Committee of Ministers of the Council of Europe on human rights and the fight against terrorism /.../." See Saadi v. Italy, § 138.

173 "As to compliance with procedural time-limits, the Court reiterates that it is in the first place for the national authorities, and notably the courts, to interpret domestic law and that it will not substitute its own interpretation for theirs in the absence of arbitrariness /.../." See Salov v. Ukraine, § 95.

174 "/.../ However, since the very essence of the applicants' right of access was not impaired and the restrictions in question pursued a legitimate aim and were proportionate, it is not for the Court to substitute its own view for that of the State authorities as to what would be the most appropriate policy in this regard." See Stubbings and others v. United Kingdom, § 56.

175 This is the reason we believe that such reasoning also relates to the interpretation of the Convention - even though it is at first sight closer to the part of the decision where judicial subsumption is carried out.

176 See Scoppola v. Italy (no. 2), § 68. 
"The guarantee enshrined in Article 7, which is an essential element of the rule of law, occupies a prominent place in the Convention system of protection /.../. It should be construed and applied, as follows from its object and purpose, in such a way as to provide effective safeguards against arbitrary prosecution, conviction and punishment $/ . . . /$."177 $^{17}$

"The Court's task in exercising its supervisory function is not to take the place of the national authorities but rather to review under Article 10, in the light of the case as a whole, the decisions they have taken pursuant to their power of appreciation /.../."178

In some cases, the teleological interpretation can be deemed as only implicit. ${ }^{179}$

\subsubsection{Historical interpretation}

When resorting to a historical interpretation, in their selected case law the Court and the ECJ deployed interpretation based on draft materials, on the intention, will etc. of the convention or charter-maker and on reasons based on the circumstances of making or modifying the Convention or Charter or their provisions in question. However, the occurrence of these forms of historical interpretation is pretty rare. Also, we did not identify cases where the Court would resort to the interpretation based on proposer justification.

For example, in the case of Šilih $v$. Slovenia, the ECtHR indirectly referred to the general intention and framework of the Convention drafters:

“/... The Court reiterates in this connection that Article 2 together with Article 3 are amongst the most fundamental provisions in the Convention and also enshrine the basic values of the democratic societies making up the Council of Europe /.../."180

An example where the Court cites the specific circumstances that existed during the preparation and subsequent conclusion of the Convention is given in the case of Engel and others $v$. The Netherlands. ${ }^{181}$

177 See Scoppola v. Italy (no. 2), § 92.

178 See Salov v. Ukraine, § 106.

179 “.../ The same applies to Article 2 cases concerning medical negligence. The State's obligation under Article 2 of the Convention will not be satisfied if the protection afforded by domestic law exists only in theory: above all, it must also operate effectively in practice and that requires a prompt examination of the case without unnecessary delays /.../." See Šilih v. Slovenia, § 195.

180 See Šilih v. Slovenia, § 147.

181 "During the preparation and subsequent conclusion of the Convention, the great majority of the Contracting States possessed defence forces and, in consequence, a system of military discipline that by its very nature implied the possibility of placing on certain of the rights and freedoms of the members of these forces limitations incapable of being imposed on civilians. The existence of such a system, which those States have retained since then, does not in itself run counter to their obligations. Military discipline, nonetheless, does not fall outside the scope of Article 5 para. 1 (art. 5-1)." See Engel and others v. The Netherlands, § 57. 


\subsubsection{Arguments based on scholarly works}

This method of interpretation is extremely rare in the analysed case law. It occurs in the case of Stagno $v$. Belgium, where the jurisprudence is mentioned both with a concrete reference and abstractly - however, not for the purposes of direct interpretation of the Convention. ${ }^{182}$

\subsubsection{Interpretation in light of general legal principles}

When interpreting the Convention, the ECtHR does not merely evolve the principles and legal standards that would be Convention-specific, but also relies on general legal principles. The content of these legal principles is not written in the text of the Convention. However, their recognition in modern law is so wide and omnipresent that they in fact represent the very foundation of law. It is hard to imagine that, for instance, the Convention would be interpreted in a way that would produce retroactive effects for member states, which would be held responsible for actions before ratifying the Convention.

General principles are inherent to law regardless of substance that is covered by particular legal sources. Their disrespect would necessarily lead to untenable, unacceptable results. Therefore, the Court takes into account the inherent general legal principles even if they are not explicitly written in the text of the Convention.

The reference to the rule of law could be regarded as the interpretation in light of general legal principles. In the case of Petri Sallinen and Others v. Finland, for example, the Court stated:

" /../ the absence of applicable regulations /.../ deprived the applicants of the minimum degree of protection to which they were entitled under the rule of law in a democratic society /.../." 183

Similarly, the principle of legal certainty can also be regarded as a general legal principle. The Court referred to this principle in the case of P.B. and J.S. v. Austria:

182 "La doctrine belge précise que le législateur a prévu un délai relativement bref afin d'éviter la disparition des preuves et des moyens de vérification. Pour l'assureur, une bonne gestion technique s'accompagne mal de litiges prolongés (M. Fontaine, " Droit des assurances », Précis de la Faculté de l'Université Catholique de Louvain, Bruxelles, 1975, no 26, p. 108). L'action en paiement de l'indemnité d'assurance est soumise à la prescription triennale, celle-ci répondant au souci du législateur de tenir compte des exigences de l'économie des compagnies d'assurance lesquelles doivent être à même de clôturer de prévisions dans un délai relativement court (Répertoire pratique du droit belge, complément III, verbo Assurances terrestres (Contrat en général), no 392)." See Stagno v. Belgium, § 16. "Elles se sont fondées pour cela sur les travaux préparatoires de la loi du 11 juin 1874, la doctrine commerciale et la jurisprudence dominante qui privilégient les intérêts des compagnies d'assurance afin de leur épargner les litiges prolongés et la disparition des preuves et des moyens de vérification." Ibid., § 29.

183 See Petri Sallinen and Others v. Finland, § 92. 
"In this context, the Court notes its case-law according to which the principle of legal certainty, which is necessarily inherent in the law of the Convention /.../."184

\subsubsection{Non-legal arguments}

The Court does not explain the substance of the Convention exclusively with legal arguments as non-legal arguments end up in legal reasoning too. In some cases, it refers to the non-legal reasons, such as public policy or sociological reasons. Sometimes these remarks can be a bit surprising and awkward. Unsurprisingly, the probability to encounter such arguments enlarges with age of the decision. In such cases we should consider that the dynamic interpretation is called dynamic precisely because the position of society on certain issues has evolved or changed for good. An example of such Court's argumentation involves a statement that all drug addicts are socially maladjusted and occasionally dangerous:

"/... In addition to vagrants, sub-paragraph (e) (art. 5-1-e) refers to persons of unsound mind, alcoholics and drug addicts. The reason why the Convention allows the latter individuals, all of whom are socially maladjusted, to be deprived of their liberty is not only that they have to be considered as occasionally dangerous for public safety but also that their own interests may necessitate their detention."185

The judges of the Court are not isolated and cut off of the world's large-scale events of processes. Thus, the Court often connects the interpretation of the Convention with specific societal circumstances and events. It then explains how this affects (or not) the interpretation of the Convention:

"The Court notes first of all that States face immense difficulties in modern times in protecting their communities from terrorist violence /.../. It cannot therefore underestimate the scale of the danger of terrorism today and the threat it presents to the community. That must not, however, call into question the absolute nature of Article 3." ${ }^{186}$

\subsection{The frequency of arguments and methods of interpretation}

As explained in the introduction to this section, our approach to presenting the statistical overview of the methods and arguments used by the ECtHR and the ECJ differs from the one applied in the section on the Constitutional Court. Here a descriptive approach to the frequency and weight of the used arguments and methods of interpretation (instead of "counting" exact frequency and occurrences of methods) 
was considered to be a more appropriate choice. However, each identified method of interpretation was assigned into the one of five groups on the ground of frequency: non-occurrence (the method has not occurred neither in any case or has occurred in less than $10 \%$ of cases); rare occurrence (the method occurs in the lower third share of cases - less than apx. $33 \%$ ); moderate occurrence (the method occurs in roughly half of cases; it may occur a bit less often or a bit more; however, it does not extend to more than two thirds share of cases); common occurrence (the method occurs in the higher third share of cases - more than apx. $66 \%$ ); constant occurrence (the method occurs in almost every case or in more than $90 \%$ of cases). ${ }^{187}$

The most frequently used method of interpretation of the Convention by the ECtHR is interpretation based on the precedents (i.e., references to specific previous decisions of the ECtHR). In every single judgment or decision considered in the analysis one could found more than one reference to the precedents (constant occurrence). Usually, there are more than 5 or even 10. However, the method of interpretation by citing the precedents is not by itself a substantive method of the interpretation of the Convention. It only takes us to what the Court previously has stated and the question, which method of interpretation led the Court to acquire a particular stance, remains unanswered.

Among the most frequently used methods of interpretation are also contextual interpretation in both narrow and broad sense and can be found in almost every selected decision (constant occurrence). However, these are very often combined with the method of citing the precedents. As already pointed out, the systemic interpretation in general and the contextual interpretation in particular is used in order to materially concretize and specify vague provisions of the Convention. As the vagueness of the Convention's provisions is not a rare phenomenon, these methods of interpretation are consequently not an exception either. On the other hand, the systemic judicial review that is conducted in specific order and steps, with the application of various tests (for example a subjective and objective test of impartiality for the purposes of Article $6 \S 1$ of the Convention) is of common, if not constant occurrence.

The analysis of the selected case law discerned a moderate occurrence of the teleological interpretation. The Court for example stresses its internationally and thus subsidiary position or a purpose of protection under the Convention in general. In some cases, it is not easy to draw a line between contextual and teleological interpretation. The teleological interpretation in broader sense, also implicitly, could reach the common occurrence threshold.

The frequency of the application of individual methods of interpretation depends also on the subject matter. For instance, in the cases where the refugees' rights were concerned, the Court more frequently cites other international treaties (and EU law) and uses them as an interpretive tool. However, in general it is not used frequently

187 The classification is not necessarily numerical, statistical correct. The presented percentages are merely of orienting purposes. 
in the selected case-law (rare-moderate occurrence), at least not for purposes of direct interpretation of the Convention. The Court cites also the case law of other international courts or tribunals, for example the ICTY, the United Nations Human Rights Committee and Inter-American Court of Human Rights (less than $10 \%$ of cases, non-occurrence).

It is a bit surprising that textual interpretation is relatively rare. The interpretation of the Convention based on an ordinary meaning of words reaches less than 10 $\%$ cases (non-occurrence) and no syntactic interpretation has been identified. However, legal professional (dogmatic) interpretation is much more frequently used. Perhaps not so much in a form of simple conceptual interpretation, but as interpretation based on legal principles. The latter is quite common and can be found in most of the selected judgments of the Court (common-constant occurrence). On the other hand, non-legal professional interpretation is virtually non-existent in the selected case law of the ECtHR as it has not occurred in the framework of direct interpretation of the text of the Convention (as the upper premise of judicial syllogism), but rather in the contextual interpretation or as part of legal subsumption (for the purposes of our research therefore the non-occurrence grade applies).

Logical arguments are rather rare or even non-existent as well. The analyses of our sample identified examples of argumentum ad absurdum and argumentum a fortiori (less than $10 \%$, non-occurrence). Among the logical arguments the most frequently used is argumentum a contrario (however, still of rare occurrence). Other logical arguments are not non-existent in the case law of the Court. However, they are rather applied in the process of subsumption (and not interpretation of the Convention itself). Argumentum a maiore ad minus has not been identified neither as a part of judicial subsumption nor as a part of interpretation of the Convention.

A variety of interpretational tools have not been detected to be applied when interpreting the Convention and are therefore of non-occurrence for the purposes of this research. However, they may be deployed in the subsumption to the facts of the case in hand. For example, the interpretation with the reference to and analysis of the constitutional tradition or constitutional arrangements of various State Parties to the Convention with an addition of final evaluation on whether there is a (wide) consensus on the specific issue, is among the methods with a higher frequency. Similar can be said for the interpretation of the Convention on the basis of the statutory law and judicial practice of (other) member states. No direct interpretation of the Convention with references to abstract norms formed by the Court itself (e.g. the rules of procedure) or on the basis of the practice of the ordinary and constitutional courts of member states have been identified either. In our sample of case law, the Court has not resorted to the interpretation referring to abstract judicial norms, such as directives, principled rulings, law unification decisions, etc. or to the normative acts of other domestic state organs (systemic arguments). The same stands for the arguments based on scholarly works. All of the above tools of legal interpretation has been nevertheless identified in the subsumption part of reasoning. 


\subsection{The characteristics of the decision-making and style of reasoning}

\subsubsection{The characteristics and style of the ECtHR's (and ECJ's) reasoning and adjudicating}

Generally, in the first parts of the judgments and decisions (hereinafter: decisions), the ECtHR makes an overview of the procedure and circumstances of the case ("Procedure" and "The Facts"), and of the "Relevant domestic law and practice", which may include also the applicable international texts and the case law of domestic and other international fora. The Court obviously evades reviewing or commenting the presented content in these parts of the decisions. Therefore, the style of reasoning hereby is exclusively illustrative. However, the Court often does cite these initial paragraphs in the later text of the decisions, where the style of reasoning is not only illustrative, descriptive, but more of a prescriptive, normative nature. After the initial parts follows the "As to the law" / "The Law" part. This part is divided into the applicant's complaints ("Alleged violation of Article ..."). Individual complaint part begins with the presentation of the applicant's position, which is followed firstly by the procedural aspects of the complaint ("Admissibility") and secondly with the "Merits". The merits part starts with the presentation of positions of the parties to the procedure ("The parties' submissions"), which is followed by the most important part of the decision besides the operative part: "the Court's assessment" part, which contains the ratio decidendi reasoning. The Court's review is further divided into the "Relevant principles" and the "Application of the principles to the facts of the case" parts. So-structured reasoning concludes with the operative part of the decision. The decisions are not always subdivided to the same number of sections with the exact same titles. However, the main logic of the structure persists.

One of the main characteristics of the judicial reasoning could be in short described with: "da mihi facta, dabo tibi ius" (give me the facts, I will give you the law). Namely, in order to any court to decide on the matter it must first have the clear factual basis, which is then connected to the relevant law that has to be applied in the process of subsumption. ${ }^{188}$ However, the specialty of the constitutional courts and the international court as the ECtHR or ECJ (especially when the fundamental rights are concerned) lies in the fundamental focus on the construction of the upper premise of the judicial decision-making. Fact-finding part of the judicial procedure happens before the domestic courts and the ECtHR is in general bind by the established facts (as often in law, there are also important exceptions; for example, in the refugees cases the Court stated that it can obtain relevant information also proprio motu). The focus before the Court is therefore on the applying relevant law to the given facts of the case. However, the facts are in general considered broader before the Court as they include also legal arguments of domestic courts. 
The very structure of the decisions of the ECtHR reveals these and other characteristics and styles of reasoning. The process of subsumption is, for example, rather clearly recognizable in the following subtitles of the parts of decisions:

“2. The Court's assessment

a) Relevant principles

/.../

b) Application of the principles to the facts of the case". ${ }^{189}$

The above-described initial parts of the decision, such as "Relevant domestic law and practice", is not the only occasion where the Court uses the illustrative style. It is quite frequent also in the later "As to the law" / "The Law" part of the decisions, where the points of the applicant and the government are presented. As the summary of these must be as accurate as possible, any other style of reasoning (than the one we named hereby as illustrative) would be inappropriate. However, in the parts that contain the Court's assessment, the Court often polemicizes with the presented government's and applicant's position by serving the reasons why it follows them or depart from them. ${ }^{190}$ This style of reasoning is highly discursive and dialectical.

An example of highly discursive style of reasoning is the one where in reviewing the issue of whether the measure had a sufficient basis in domestic law, the Court first found that none of the concrete legislative provisions was explicitly referred to in the domestic court's judgments. Then it stressed: "However, in the light of the available materials, and notably, the Government's observations, the Court is prepared to accept that collection, storage, and other use of the applicant's mental health had some basis in domestic law." ${ }^{191}$ The cited text demonstrates that it was not the Court's review of the reasoning of the domestic court's judgments from the point of view of the Convention which has been decisive but the presented materials and Government's position in the procedure before the ECtHR. These arguments were deemed as decisive by the Court.

An example of highly discursive style of reasoning is also the finding of the Court that there is no dispute regarding a certain issue between the applicant and the Government. This is more so since such finding of the Court substitutes the reasons which would be given if there would be a dispute, which are in fact the only valid reasons vis-à-vis the Convention. ${ }^{192}$

189 See for example Płaza v. Poland, § 70-75.

190 "The Court finds that the Government have not submitted any convincing arguments in the instant case which would require the Court to distinguish it from its established case-law." See Švarc and Kavnik v. Slovenia, § 22.

191 Surikov v. Ukraine, § 79.

192 The example would be: "The Court notes at the outset that it is not in dispute between the parties that the applicant's criminal conviction constituted an interference with the exercise of his right to freedom of expression, as guaranteed by Article 10 of the Convention. That is also the Court's opinion." See Morice v. France, § 141. 
The discursive reasoning is not in all cases connected with the material (i.e., substantial) arguments. Sometimes, it can be linked to rather procedural aspects of the reasoning. Such example is a question regarding the burden of proof and whether this requirement has been fulfilled. ${ }^{193}$

The Court's reasoning is on the other hand not always discursive and detailed. Rarely it resembles more of quasi-ex cathedra statements. However, in most such cases, this style of argumentation is used when the stated is obvious or seems to be generally accepted/known and therefore needs no further explanation. ${ }^{194}$ Where the Court's statement is obvious and therefore comprises only a sentence or two, this is expressed by, for example, citing "the very nature" of the issue at hand. ${ }^{195}$ In some instances, however, the very concise reasoning evokes the impression that not all the criteria have been presented in detail and transparently. ${ }^{196}$

Besides citing the precedents, one of the main characteristics of the Court's reasoning is the application of several tests, ${ }^{197}$ standards and argumentative forms of review. The aim of such reasoning is clear: to achieve the objectivity, foreseeability and generality (as the opposition to casuistic adjudicating) and to demonstrate the rationality of the decision-making process. Turning to various, more or less complicated forms and assessment steps of the review, also contributes to the structure and systematicity of the reasoning. It comes as no surprise that often these arguments have a decisive weight in the reasoning of the decisions. These tests are not only formal forms that would be applicable to any right and issue. They are often content-specific and

193 "In this connection, the Court notes that the Government failed to adduce any case-law of the domestic courts to show that a civil action for the protection of personal rights brought against the State Treasury or an action for compensation for non-pecuniary damage under Article 448 of the Civil Code could be successfully invoked /.../." See Płaza v. Poland, § 56.

194 For example: „In view of the submissions of the applicant in the present case and of the grounds on which it has found a violation of Article 8 of the Convention, the Court considers that there is no need to examine separately the complaints under Article 13 of the Convention." See Petri Sallinen and Others v. Finland, § 110.

195 "The Court notes that the information at stake in the present case concerned an indication that in 1981 the applicant had been certified as suffering from a mental health related condition. The Court concludes that such information by its very nature constitutes highly sensitive personal data regardless of whether it was indicative of a particular medical diagnosis.« See Surikov v. Ukraine, $\S 75$. "However, this right is not absolute, but may be subject to limitations; these are permitted by implication since the right of access by its very nature calls for regulation by the State." See Stubbings and Others v. the United Kingdom, § 50.

196 "The Court observes that the impugned sets of proceedings lasted, respectively, one year and ten months before two judicial instances and two years and two months, also before two judicial instances.

Having regard to the criteria referred to above and to the circumstances at issue, the Court is of the view that the length of the proceedings concerned did not exceed what could be considered reasonable, due regard being had to the fact that parent-child proceedings require to be handled expeditiously." See Płaza v. Poland, § 49, 50.

197 For example, the objective and subjective test of impartiality; the well-known test of proportionality (the pressing social need; necessary in a democratic society; the proportional interference in comparison to the legitimate aims pursued), the legitimate aims test, the standard of quality of law (in the framework of "in accordance with law" requirement) and many others. 
linked with developed substantial legal standards. Therefore, they are not merely the tool for subsumption, but also a method for interpretation of Convention's provisions.

The Court often adds also other, strengthening and defining arguments and reasons to the decisive ones. And often does it explicitly with the conjunctions as "moreover", "lastly", "In addition", 198 "furthermore", "it should also be borne in mind" 199 etc. An example of a complete strengthening argument goes as follows: "This approach finds support also in the jurisprudence of the United Nations Human Rights Committee and, in particular, of the Inter-American Court of Human Rights, which, though under different provisions, accepted jurisdiction ratione temporis over the procedural complaints relating to deaths which had taken place outside their temporal jurisdiction /.../."200

The above-mentioned aim to achieve the foreseeability and generality in some cases remains unattainable as the strong casuistic element is present. For example, in the following case the Court explicitly stated:

"The Court takes the view, however, that the very singular context of the case cannot be overlooked. /.../.".201

The Court in some cases explicitly relativizes the strict standards of review. The purpose of such reasoning must be taken into account. It is welcoming that this is transparent. However, it could in the extreme lead to the detriment of the foreseeability of the Convention interpretation and decision-making. Such an approach seems to be less problematic when it is aimed to wider the access to the court or to guarantee a wider scope of the protection. ${ }^{202}$

Lastly, in the analysis the examples of rather non-legal and/or to some extent unconventional (unusual) style of reasoning has been detected as well:

"In any event, it is hard to understand how the decision to declare the application admissible could "prejudice the assessment" of the Grand Chamber."203

"What strikes one first when examining the circumstances surrounding Neumeister's second detention is that /.../. Lastly, it is indeed disappointing that the trial was not able to commence before $/ \ldots /$, and even more disappointing that, following such a long investigation, /.../. Neither does the Court believe that the course of the investigation would have been accelerated, if it had been allocated to more than one judge, even supposing that this had been legally possible." ${ }^{204}$

198 See for example Scoppola v. Italy, § 71, 76, 142.

199 See Leander v. Sweden, § 55, 84.

200 See Šilih v. Slovenia, § 160.

201 Morice v. France, $\S 84$. The emphasis added by the author.

202 »The rule of exhaustion of domestic remedies must be applied with some degree of flexibility and without excessive formalism.« See Scoppola v. Italy, § 69.

203 See Scoppola v. Italy, § 59. Emphasis added by the author.

204 See Neumeister v. Austria, § 8, 20, 21. Emphasis added by the author. 
"The Court is of course aware that the systematic terror applied to consolidate communist rule in several countries, including Hungary, remains a serious scar in the mind and heart of Europe. /.../ Given the well-known assurances which the Republic of Hungary provided legally, morally and materially to the victims of communism, such emotions cannot be regarded as rational fears. /.../."205

\subsubsection{Concluding on the characteristics of the decision-making of the ECtHR (and ECJ)}

The methods of the interpretation, the reasoning style and characteristics of decision-making clearly resonate the international-law / supranational-law position of the ECtHR (and ECJ). The ECtHR often sails between Scylla and Charybdis of the status quo regarding the level of international protection of human rights on the one hand and the too progressive and therefore self-endangering adjudicating that would be labelled by some as judicial activism. ${ }^{206}$

The choice of the methods of the interpretation of the Convention and the style of the reasoning is often affected by the above presented challenge: the Court regularly reviews the broader consensus among the Convention parties and also refers to their constitutional traditions and other relevant legal sources. On the basis of the comparative arguments it then determines, for example, the strictness of the review on the case-by-case basis (this is mostly done by using the margin of appreciation concept) as it would try to find out how high it is capable to push the bar of protection of human rights at stake in order not to overstep the Rubicon. ${ }^{207}$

The fundamental interpretative tool of the Court are the precedents, which can be seen already from the structure of the decisions. Precedents are of the decisive importance especially in the parts of the decisions where the general principles are presented and construed, which are then applied to the facts of the case in hands. However, the decisive arguments are not delivered by the Court only via the precedents, but often also through the reasoning with the well-established legal standards, tests and principles.

The finding that the decisive reasons are delivered via the precedents and argumentative forms of reasoning leads also to the conclusion on the style of reasoning

205 See Vajnai v. Hungary, § 57.

206 This challenge is illustrated by the following reasoning of the Court: "While the Court is not formally bound to follow any of its previous judgments, it is in the interests of legal certainty, foreseeability and equality before the law that it should not depart, without cogent reason, from precedents laid down in previous cases (see, for example, Chapman v. the United Kingdom [GC], no. 27238/95, $\S 70$, ECHR 2001-I). Since the Convention is first and foremost a system for the protection of human rights, the Court must however have regard to the changing conditions in the respondent State and in the Contracting States in general and respond, for example, to any emerging consensus as to the standards to be achieved /.../ A failure by the Court to maintain a dynamic and evolutive approach would risk rendering it a bar to reform or improvement (see Stafford, cited above, § 68, and Christine Goodwin v. the United Kingdom [GC], no. 28957/95, § 74, ECHR 2002-VI)." See Scoppola v. Italy, § 104.

207 The telling is in our view the case of Stubbings and Others v. the United Kingdom, see § 54-56. 
pursued by the Court. There is no doubt that the values of objectivity, rationality, coherence, foreseeability and generality of the adjudicating are being pursued.

\section{Conclusion}

As emphasized, our approach in studying the selected decisions of the Slovenian Constitutional Court on the one hand, and the ECtHR (and ECJ) case law on the other, was based on a common methodology, but we had to adjust its application due to the differences between the two courts. Indeed, the research has revealed significant differences between both courts regarding characteristics of their decision-making and their style of reasoning and adjudicating. However, there are also important similarities in the adjudication of both courts which are primarily a consequence of the fact that they both decide upon fundamental rights violations.

For example, there are considerable differences between the Constitutional Court and the ECtHR in the type of cases they decide upon and the way they deal with the cases as well as in the structure of their decisions, which is a consequence of the differences in their jurisdiction. Commonly, the Constitutional Court's decisions and orders contain the statement of the legal basis for deciding, the operative provisions, the statement of reasons and, at the very end, the statement of the composition of the Constitutional Court which reached the decision. A decision also includes a statement on the results of the vote and the names of the Constitutional Court judges who voted against the decision, the names of the Constitutional Court judges who submitted separate opinions, and the names of the Constitutional Court judges who were disqualified from deciding.

The characteristics of decision-making of the Constitutional Court largely depend on the type of a case. A norm control proceeding may be initiated by the submission of a written request by the applicants determined by the Constitutional Court Act or by a Constitutional Court order on the acceptance of a petition to initiate a review procedure, which may be lodged by anyone who demonstrates legal interest. In the latter type of cases, prior to adjudicating on the merits of a case, the Constitutional Court examines the petition, determining whether the petitioner has demonstrated legal interest. In the reasoning of its final/decisions in norm control proceedings, the Constitutional Court first provides a summary of the allegations of petitioners or applicants and then gives reasons for the decision on the (un)constitutionality of the challenged provisions of laws or other general acts. The Court carries out the review of constitutionality on the basis of the test of legitimacy, which entails an assessment of whether the legislature or other law-giving entity pursued a constitutionally admissible objective, and on the basis of the strict test of proportionality, which comprises an assessment of whether the interference was appropriate, necessary, and proportionate in the narrower sense. 
In the constitutional complaint cases, the characteristics of decision-making of the Constitutional Court depend on the characteristics and peculiarities of proceedings in this type of cases. Prior to deciding on the merits of a case, the Constitutional Court decides in a panel of three judges at a closed session whether to initiate proceedings. The panel decides on the acceptance or rejection of the constitutional complaint in a fashion and according to criteria determined by the Constitutional Court Act. When deciding on the merits of a case, the Constitutional Court either dismisses a constitutional complaint as unfounded or grants it and in whole or in part annuls or abrogates the individual act, and remands the case to the authority competent to decide thereon. In the reasoning of its orders concerning the admissibility of a constitutional complaint, the Constitutional Court summarizes the proceedings before the courts of general jurisdiction, lists the decisions that are challenged by the constitutional complaint, presents the complainant's allegations and gives reasons for the decision regarding the admissibility of a constitutional complaint. It also clarifies the reasons for suspension if in the procedure for examining the constitutional complaint the challenged individual act has been temporary suspended. In the reasoning of its final/substantive decisions, however, the Constitutional Court first summarizes once again the proceedings before the regular courts and lists the decisions that are challenged by the constitutional complaint. It then presents the complainant's allegations and arguments in more detail, while also referring to the challenged decisions and their statements. In the main section(s) of the final decision's reasoning, the Constitutional Curt reiterates the key allegations of the complainant, adjudicates on their merits and provides a detailed argumentation of its decision.

In its judgments, the ECtHR first makes in sections called "Procedure" and "As to the Facts" an overview of the procedure and circumstances of the case and of the "Relevant domestic law and practice", which may include also the case law of domestic and other international fora. After the initial parts follow the "As to the law" part and the part titled "Alleged violation of Article /.../" where the applicant's position is presented. This is followed firstly by the procedural aspects of the complaint ("Admissibility") and secondly with the "Merits". The merits part starts with the presentation of positions of the parties to the procedure ("The parties' submissions") and continues by "the Court's assessment", which contains the reasoning. Although the decisions are not always subdivided to the same number of sections with the exact same titles, commonly, the Court's review in this part is further divided into the "Relevant principles" and the "Application of the principles to the facts of the case" parts. So-structured reasoning concludes with the operative part of the decision (in contrast to the Constitutional Court's decisions, the operative provisions are at the end of a judgement).

The reasoning style and characteristics of decision-making clearly resonate the supranational-law position of the ECtHR. In the decision-making process, the fundamental focus of the ECtHR seems to be in the construction of the upper premise of the judicial decision-making, which is also characteristic of decision-making of the Constitutional Court. Fact-finding part of the judicial procedure happens before the 
domestic courts. Generally, the ECtHR is bind by the established facts, but, as often in law, there are also important exceptions. The focus before the Court is therefore on the applying relevant law to the given facts of the case. However, the facts are considered broader before the Court as they include also legal arguments of domestic courts.

While the Court's style of reasoning is similar in the individual and state complaints proceedings, it differs in the different parts of a judgement. While in the initial part of the judgement the style of reasoning is illustrative and descriptive, in the later parts it becomes more of a prescriptive and normative nature. This is also characteristic of the Constitutional Court. Namely, in order to decide on the matter the both courts must first have the clear factual basis, which is then connected to the relevant law that has to be applied in the process of subsumption. In the part of a judgement that contain the Court's assessment, the ECtHR often polemicizes with the presented government's and applicant's position by serving the reasons why it follows them or depart from them. Here the style of reasoning is highly discursive and dialectical, which, in our view, applies - perhaps to a slightly lesser extent - also to the main part of the reasoning in the Constitutional Court' decisions (i.e., in both main types of cases).

The length of the decisions and their reasoning depends on the substance and complexity of each individual case. While the majority of final decisions of the Constitutional Court comprise on average between seven and fifteen pages, in most cases judgements of the ECtHR are slightly longer. Occasionally they may have thirty or even forty pages.

Regarding the frequency and weight of the used interpretative tools we found some important similarities in the case law of both courts. When reasoning their decisions and determining the meaning of the Constitution/Convention, the most frequently deployed method is the interpretation on the basis of case law of each court. Regarding this method of interpretation, the most frequently used by both courts are references to specific previous decisions as precedents. The frequency and total number of deployments of other types of domestic systemic arguments and methods of interpretation is significantly smaller in the case law of both courts.

Another systemic interpretative technique frequently used by both courts is $a$ contextual interpretation in a narrow and/or broad sense. In the selected case law of the Constitutional Court and the ECtHR this method was found in almost every decision. However, in the case law of both courts, this method is often combined with referring to specific previous decisions as precedents. This is no surprise as both the systemic interpretation in general and the contextual interpretation in particular are used in order to substantially concretize and specify vague provisions of the Constitution/Convention.

In general, the interpretation of fundamental rights on the basis of international treaties (other than the Convention) has been deployed very rarely by the ECtHR and not very often by the Constitutional Court, at least not for purposes of direct interpretation of the Constitution/Convention. However, in the cases where the refugees' 
rights were concerned, both courts have made numerous references to other international treaties and EU law and used them as an interpretive tool. This led us to a conclusion that the frequency of the application of individual methods of interpretation depends also on the subject matter.

Among different types of grammatical (textual) interpretation, no syntactic interpretation has been identified and the interpretation based on an ordinary meaning of words was deployed relatively rarely in the selected case law of both courts. Similarly, the non-legal professional interpretation has not been identified in our sample of the Constitutional Court's case law and is virtually non-existent in the selected case law of the ECtHR (it has not occurred in the framework of direct interpretation of the text of the Convention). The legal professional (dogmatic) interpretation, however, has been much more frequently used by both courts.

Somewhat surprisingly logical arguments are rather rare or even non-existent in the selected case law of both courts as well. Among these arguments, although very rarely, both courts have used argumentum a contrario. The analyses of the ECtHR's selected judgements identified examples of argumentum ad absurdum and argumentum a fortiori, which were not identified in the decisions of the Constitutional Court. While argumentum a maiore ad minus has been used several times by the Constitutional Court, it has not been identified in the judgements of the ECtHR, not even as a tool of judicial subsumption.

The study of the selected case law of both courts revealed a moderate occurrence of the teleological interpretation, if considered in a narrow sense. The analyses also discerned that in some cases it is not easy to distinguish between contextual, historical and teleological interpretation, since the latter, in a broad sense, includes all arguments referring to the purpose, meaning, function, aim, etc. of the Constitution/ Convention.

Altogether, some interpretational tools in some cases have not been detected to be applied for the purpose of a direct interpretation of the Constitution/Convention, however, they have been deployed in the subsumption to the facts of the case in hand. This, for example, refers to the interpretation by the ECtHR of Convention on the basis of domestic statutory law and citations of the ECtHR of the case law of Constitutional courts. Last but not least, perhaps the most significant difference between the two courts concerns the use of arguments based on scholarly works. While being the third most frequently used interpretative technique in the selected decisions of the Slovenian Constitutional Court, this method is virtually non-existing in the selected judgements of the ECtHR.

Besides using different methods/techniques of interpretation and argumentation, one of the main characteristics of the reasoning style of both courts is the application of several tests, standards and argumentative forms of review. By deploying them, both courts try to achieve the objectivity, foreseeability, generality and rationality of the decision-making process. Interestingly, both courts in some cases explicitly relativize the strict standards of review. Such approach to reasoning is aimed to wider the access to the courts or to guarantee a wider scope of the protection. However, it 
could in the extreme lead to the detriment of the foreseeability of the Constitution/ Convention interpretation and decision-making of the courts. In other words, both courts often sail between Scylla and Charybdis of the status quo regarding the level of national and international protection of human rights on the one hand and the too progressive adjudicating that could be labelled as judicial activism. 


\section{Bibliography}

ARAI, Y. (2002) The margin of appreciation doctrine and the principle of proportionality in the jurisprudence of the ECHR. Antwerp; Oxford; New York: Intersentia.

Constitutional Court of the RS. (2020) Poročilo o delu 2019 [The Constitutional Court of the Republic of Slovenia - An Overview of the Work for 2019]. Ljubljana: Ustavno sodišče RS. Retrieved from: https://www.us-rs.si/wp-content/uploads/2020/05/usrs_ letnoporocilo_2019.pdf [Accessed: 22. 4. 2021].

KAUČIČ, I. AND GRAD, F. (2011) Ustavna ureditev Slovenije [The Constitutional Order of Slovenia]. 5th edn. Ljubljana: GV založba.

KRIVIC, M. (2000) 'Ustavno sodišče: pristojnosti in postopek' [The Constitutional Court: Powers and Proceedings] in Pavčnik, M. and Mavčič, A. (eds.) Ustavno sodstvo [The Constitutional Judiciary]. Ljubljana: Cankarjeva založba, pp. 47-211.

TESTEN, F. (2000) 'Tehnike ustavnosodnega odločanja' [Techniques of Constitutional Adjudication] in Pavčnik, M. and Mavčič, A. (eds.) Ustavno sodstvo [The Constitutional Judiciary]. Ljubljana: Cankarjeva založba, pp. 213-249.

FIŠER, Z. (2000) 'Ustavna pritožba v kazenskih zadevah' [Constitutional complaint in criminal matters] in Pavčnik, M. and Mavčič, A (eds.) Ustavno sodstvo [The Constitutional Judiciary]. Ljubljana: Cankarjeva založba, pp. 275-300.

MAvČıč, A. (2000) Zakon o ustavnem sodišču s pojasnili [The Constitutional Court Act with Explanations]. Ljubljana: Nova revija.

NERAD, S. (2007) Interpretativne odločbe Ustavnega sodišča [The Interpretative Decisions of the Constitutional Court]. Ljubljana: Uradni list Republike Slovenije.

PAVČNIK, M. (2008) 'Hin- und Herwandern des Blickes', Rechtstheorie, 39(4), pp. 557-572.

PAVČNIK, M. (2000) 'Pravni in ustavn temelji prava. Glosa k nekaterim ustavnosodnim argumentom' [Legal and constitutional foundations of law. Gloss to Some Constitutional Judicial Arguments] in Pavčnik, M. and Mavčič, A. (eds.) Ustavno sodstvo [The Constitutional Judiciary]. Ljubljana: Cankarjeva založba, pp. 391-431.

PAVČNIK, M. (2013) Teorija prava: prispevek $k$ razumevanju prava [Theory of Law: A Contribution to the Understanding of Law]. 4th edn. Ljubljana: GV Založba.

PAVČNIK, M. (2013a) Argumentacija v pravu: od življenjskega primera do pravne odločitve [Argumentation in law: from a life case to a legal decision]. $3^{\text {rd }}$ edn. Ljubljana: GV Založba.

TóтH, Z. J. (2016) 'The Methods of Statutary Interpretation in the Practice of the High Courts in Hubgary', Annales Universitatis Mariae Curie Skladovska, Vol I., pp. 173-201.

UDE, L. (1995) Ustavna pritožba kot pravno sredstvo (Pooblastila Ustavnega sodišča pri preiskusu sodnih odločb) [Constitutional appeal as a remedy (Powers of the Constitutional Court in the review of court decisions)]. Podjetje in delo, 5-6/1995/XXI, pp. 514-522. 


\section{List of selected decisions}

\begin{tabular}{|c|c|c|}
\hline 1. & $\begin{array}{l}\text { Decision Up-1293/08 of the Constitu- } \\
\text { tional Court, dated } 6 \text { July } 2011\end{array}$ & Allan v. UK, judgement of 5 November 2002 \\
\hline 2. & $\begin{array}{l}\text { Decision U-I-109/10 of the Constitu- } \\
\text { tional Court, dated } 26 \text { September } 2011\end{array}$ & $\begin{array}{l}\text { Vajnai v. Hungary, judgement of } 8 \text { October } \\
2008\end{array}$ \\
\hline 3. & $\begin{array}{l}\text { Decision Up- } 457 / 09 \text { of the Constitu- } \\
\text { tional Court, dated } 28 \text { September } 2011\end{array}$ & $\begin{array}{l}\text { Roşca v. Moldavia, judgement of } 22 \text { March } \\
2005\end{array}$ \\
\hline 4. & $\begin{array}{l}\text { Decision U-I-292/09, Up-1427/09 of } \\
\text { the Constitutional Court, dated } 20 \\
\text { October } 2011\end{array}$ & $\begin{array}{l}\text { Vilvarajah and others v. the United Kingdom, } \\
\text { judgement of } 30 \text { October } 1991\end{array}$ \\
\hline 5. & $\begin{array}{l}\text { Decision Up-570/09 of the Constitu- } \\
\text { tional Court, dated } 2 \text { Februar } 2012\end{array}$ & $\begin{array}{l}\text { Novaya Gazeta V Voronezhe v. Russia, } \\
\text { judgement of } 21 \text { December } 2010\end{array}$ \\
\hline 6. & $\begin{array}{l}\text { Decision Up-444/09 of the Constitu- } \\
\text { tional Court, dated } 12 \text { April } 2012\end{array}$ & $\begin{array}{l}\text { Benediktsdóttir v. Iceland, judgement of } 16 \\
\text { June } 2009\end{array}$ \\
\hline 7. & $\begin{array}{l}\text { Decision U-I-24/10 of the Constitu- } \\
\text { tional Court, dated } 19 \text { April } 2012\end{array}$ & $\begin{array}{l}\text { Engel and others v. Netherland, judgement } \\
\text { of } 8 \text { June } 1976\end{array}$ \\
\hline 8. & $\begin{array}{l}\text { Decision Up-21/11 of the Constitu- } \\
\text { tional Court, dated } 10 \text { October } 2012\end{array}$ & Amuur v. France, judgement of 25 June 1996 \\
\hline 9. & $\begin{array}{l}\text { Decision U-I-212/10 of the Constitu- } \\
\text { tional Court, dated } 14 \text { March } 2013\end{array}$ & $\begin{array}{l}\text { P. B. and J. S. v. Austria, judgement of } 22 \\
\text { July } 2010\end{array}$ \\
\hline 10. & $\begin{array}{l}\text { Decision Up-336/13 of the Constitu- } \\
\text { tional Court, dated } 16 \text { May } 2013\end{array}$ & $\begin{array}{l}\text { Neumeister v. Austria, judgement of } 27 \text { June } \\
1968\end{array}$ \\
\hline 11. & $\begin{array}{l}\text { Decision U-I-40/12 of the Constitu- } \\
\text { tional Court, dated } 11 \text { April } 2013\end{array}$ & $\begin{array}{l}\text { Buck v. Germany, judgement of } 28 \text { April } \\
2005\end{array}$ \\
\hline 12. & $\begin{array}{l}\text { Decision Up-383/11-26 of the Consti- } \\
\text { tutional Court, dated } 18 \text { September } \\
2013\end{array}$ & $\begin{array}{l}\text { Petri Sallinen and others v. Finland, } \\
\text { judgement of } 27 \text { September } 2005\end{array}$ \\
\hline 13. & $\begin{array}{l}\text { Decision Up-1056/11 of the Constitu- } \\
\text { tional Court, dated } 21 \text { November } 2013\end{array}$ & $\begin{array}{l}\text { Płaza v. Poland, judgement of } 25 \text { January } \\
2011\end{array}$ \\
\hline
\end{tabular}




\begin{tabular}{|c|c|c|}
\hline 14. & $\begin{array}{l}\text { Decision U-I-155/11 of the Constitu- } \\
\text { tional Court, dated } 18 \text { December } 2013\end{array}$ & $\begin{array}{l}\text { T. I. v. United Kingdom, judgement of } 7 \\
\text { March } 2000\end{array}$ \\
\hline 15. & $\begin{array}{l}\text { Decision Up-540/11 of the Constitu- } \\
\text { tional Court, dated } 13 \text { February } 2014\end{array}$ & $\begin{array}{l}\text { M. S. S. v. Belgium and Greece, judgement of } \\
21 \text { January } 2011\end{array}$ \\
\hline 16. & $\begin{array}{l}\text { Decision U-I-115/14, Up-218/14-45 } \\
\text { of the Constitutional Court, dated } 21 \\
\text { January } 2016\end{array}$ & $\begin{array}{l}\text { K. U. v. Finland, judgement of } 2 \text { December } \\
2008\end{array}$ \\
\hline 17. & $\begin{array}{l}\text { Decision Up-1177/12, Up-89/14-15 } \\
\text { of the Constitutional Court, dated } 28 \\
\text { May } 2015\end{array}$ & Stagno v. Belgium, judgement of 7 July 2009 \\
\hline 18. & $\begin{array}{l}\text { Decision Up-879/14 of the Constitu- } \\
\text { tional Court, dated } 20 \text { April } 2015\end{array}$ & $\begin{array}{l}\text { Švarc and Kavnik v. Slovenia, judgement of } 8 \\
\text { February } 2007\end{array}$ \\
\hline 19. & $\begin{array}{l}\text { Decision U-I-122/13 of the Constitu- } \\
\text { tional Court, dated } 10 \text { March } 2016\end{array}$ & $\begin{array}{l}\text { Volker und Markus Schecke GbR and } \\
\text { Hartmut Eifert v. Land Hessen, C-92/09 and } \\
\text { C- } 93 / 09 \text {, dated } 9 \text { November } 2010\end{array}$ \\
\hline 20. & $\begin{array}{l}\text { Decision Up-680/14 of the Constitu- } \\
\text { tional Court, dated } 5 \text { May } 2016\end{array}$ & Šilih v. Slovenia, judgement of 9 April 2009 \\
\hline 21. & $\begin{array}{l}\text { Decision Up- } 450 / 15 \text { of the Constitu- } \\
\text { tional Court, dated 2. June } 2016\end{array}$ & $\begin{array}{l}\text { Stubbings and others v. United Kingdom, } \\
\text { judement of } 22 \text { October } 1996\end{array}$ \\
\hline 22. & $\begin{array}{l}\text { Decision Up-1006/13 of the Constitu- } \\
\text { tional Court, dated } 9 \text { June } 2016\end{array}$ & $\begin{array}{l}\text { Salov v. Ukraine, judgement of } 6 \text { September } \\
2005\end{array}$ \\
\hline 23. & $\begin{array}{l}\text { Decision Up-217/15 of the Constitu- } \\
\text { tional Court, dated } 7 \text { July } 2016\end{array}$ & $\begin{array}{l}\text { Švarc and Kavnik v. Slovenia, judgement of } \\
8 \text { May } 2007\end{array}$ \\
\hline 24. & $\begin{array}{l}\text { Decision Up-402/12, U-I-86/12 of the } \\
\text { Constitutional Court, dated } 6 \text { July } \\
2016\end{array}$ & $\begin{array}{l}\text { Niedbala v. Poland, judgement of } 4 \text { July } \\
2000\end{array}$ \\
\hline 25. & $\begin{array}{l}\text { Decision Up- } 613 / 16 \text { of the Constitu- } \\
\text { tional Court, dated } 28 \text { September } 2016\end{array}$ & $\begin{array}{l}\text { Saadi v. Italy, judgement of } 28 \text { February } \\
2008\end{array}$ \\
\hline 26. & $\begin{array}{l}\text { Decision U-I-246/14 of the Constitu- } \\
\text { tional Court, dated } 24 \text { March } 2017\end{array}$ & $\begin{array}{l}\text { Leander v. Sweden, judgement of } 26 \text { March } \\
1987\end{array}$ \\
\hline 27. & $\begin{array}{l}\text { Decision Up-108/16 of the Constitu- } \\
\text { tional Court, dated } 6 \text { December } 2017\end{array}$ & $\begin{array}{l}\text { Scoppola v. Italy (No. 2), judgement of } 17 \\
\text { September } 2009\end{array}$ \\
\hline
\end{tabular}




\begin{tabular}{|l|l|l|}
\hline 28. & $\begin{array}{l}\text { Decision Up-793/15 of the Constitu- } \\
\text { tional Court, dated 10 October 2018 }\end{array}$ & $\begin{array}{l}\text { Morice v. France, judgement of 23 April } \\
2015\end{array}$ \\
\hline 29. & $\begin{array}{l}\text { Decision U-I-152/17 of the Constitu- } \\
\text { tional Court, dated 4 July 2019 }\end{array}$ & $\begin{array}{l}\text { Surikov v. Ukraine, judgement of 26 January } \\
2017\end{array}$ \\
\hline 30. & $\begin{array}{l}\text { Decision U-I-83/20 of the Constitu- } \\
\text { tional Court, dated 27 August 2020 }\end{array}$ & $\begin{array}{l}\text { Guzzardi v. Italy, judgement of 6 November } \\
1980\end{array}$ \\
\hline
\end{tabular}


BENJAMIN FLANDER

\begin{tabular}{|c|c|c|c|c|c|c|c|c|}
\hline & Iethoc & & $\begin{array}{l}\text { Frequency } \\
\text { (number) }\end{array}$ & $\begin{array}{c}\text { Frequency } \\
(\%)\end{array}$ & $\begin{array}{l}\text { Main types } \\
\text { frequency } \\
\text { (number and }\end{array}$ & $\begin{array}{c}\text { Weight } \\
\text { (number) }\end{array}$ & $\begin{array}{c}\text { Weight } \\
(\%)\end{array}$ & $\begin{array}{c}\text { Main types } \\
\text { weight } \\
\text { (number }\end{array}$ \\
\hline & & a) & 10 & $4 \%$ & & 12 & $1 \%$ & \\
\hline & $1 / R$ & b) & 0 & $0 \%$ & & 0 & $0 \%$ & \\
\hline 1 & $1 / \mathrm{P}$ & a) & 27 & \#\#\# & $29 / 30(97 \%)$ & 85 & $9 \%$ & 107 (11\%) \\
\hline & ס & b) & 7 & $3 \%$ & & 10 & $1 \%$ & \\
\hline & $1 / \mathrm{C}$ & & 0 & $0 \%$ & & 0 & $0 \%$ & \\
\hline & $2 / \mathrm{A}$ & & 0 & $0 \%$ & & 0 & $0 \%$ & \\
\hline & $2 / \mathrm{B}$ & & 2 & $1 \%$ & & 5 & $1 \%$ & \\
\hline 2 & $2 / \mathrm{C}$ & & 0 & $0 \%$ & $2 / 20(100)$ & 0 & $0 \%$ & $6(100)$ \\
\hline 2 & $2 / \mathrm{D}$ & & 1 & $0 \%$ & $3 / 30(10 \%)$ & 1 & $0 \%$ & $0(1 \%)$ \\
\hline & $2 / \mathrm{E}$ & & 0 & $0 \%$ & & 0 & $0 \%$ & \\
\hline & $2 / \mathrm{F}$ & & 0 & $0 \%$ & & 0 & $0 \%$ & \\
\hline & $3 / \mathrm{A}$ & & 26 & \#\#\# & & 89 & $9 \%$ & \\
\hline & $3 / \mathrm{B}$ & & 18 & $7 \%$ & & 50 & $5 \%$ & \\
\hline & & a) & 30 & \#\#\# & & \#\# & \#\#\# & \\
\hline & $3 / \mathrm{C}$ & b) & 16 & $7 \%$ & & 25 & $3 \%$ & \\
\hline 3 & & c) & 0 & $0 \%$ & $30 / 30(100 \%)$ & 0 & $0 \%$ & $466(50 \%)$ \\
\hline & & a) & 1 & $0 \%$ & & 1 & $0 \%$ & \\
\hline & $3 / \mathrm{D}$ & b) & 5 & $2 \%$ & & 21 & $2 \%$ & \\
\hline & & c) & 0 & $0 \%$ & & 0 & $0 \%$ & \\
\hline & $3 / \mathrm{E}$ & & 0 & $0 \%$ & & 0 & $0 \%$ & \\
\hline & 4/A & & 21 & $9 \%$ & & 61 & $6 \%$ & \\
\hline 4 & 4/B & & 30 & \#\#\# & $30 / 30(1000 \%$ & \#\# & \#\#\# & $232(240 \%$ \\
\hline 4 & $4 / C$ & & 8 & $3 \%$ & $30 / 30(100 \%)$ & 12 & $1 \%$ & $232(24 \%)$ \\
\hline & $4 / D$ & & 1 & $0 \%$ & & 1 & $0 \%$ & \\
\hline 5 & & & 9 & $4 \%$ & $9 / 30(30 \%)$ & 24 & $3 \%$ & $24(2 \%)$ \\
\hline & $6 / \mathrm{A}$ & & 0 & $0 \%$ & & 0 & $0 \%$ & \\
\hline 6 & $6 / \mathrm{B}$ & & 0 & $0 \%$ & $1 / 30(20 /)$ & 0 & $0 \%$ & $1(00 \%)$ \\
\hline 0 & $6 / \mathrm{C}$ & & 1 & $0 \%$ & $1 / 30(3 \%)$ & 1 & $0 \%$ & $1(0 \%)$ \\
\hline & $6 / D$ & & 0 & $0 \%$ & & 0 & $0 \%$ & \\
\hline 7 & & & 25 & $10 \%$ & $25 / 30(83 \%)$ & 102 & $11 \%$ & $102(10 \%)$ \\
\hline 8 & & & 4 & $2 \%$ & 4/30 (13\%) & 11 & $1 \%$ & $11(1 \%)$ \\
\hline 9 & & & 3 & $1 \%$ & $3 / 30(10 \%)$ & 8 & $1 \%$ & $8(1 \%)$ \\
\hline
\end{tabular}




\section{Legend:}

1. Grammatical (textual) interpretation

$1 / A$. Interpretation based on ordinary meaning

a) Semantic interpretation

b) Syntactic interpretation

1/B. Legal professional (dogmatic/doctrinal) interpretation:

a) Simple conceptual dogmatic/doctrinal interpretation

b) Interpretation on the basis of legal principles

$1 /$ C. Other professional interpretation

2. Logical (linguistic-logical) arguments

2/A. Argumentum a minore ad maius

$2 / B$. Argumentum a maiore ad minus

$2 / C$. Argumentum ad absurdum

2/D. Argumentum a contrario / arguments from silence

$2 / E$. Argumentum a simili and, within it, analogy

$2 / F$. Interpretation according to other logical maxims

3. Domestic systemic arguments

3/A. Contextual interpretation, in a narrow and broad sense

$3 / B$. Interpretation of constitutional norms on the basis of domestic staturory law

$3 / C$. Interpretation of the constitution on the basis of case law of the Constitutional Court

a) References to specific previous decisions of the Constitutional Court (as "precedents")

b) References to the "practice" of the Constitutional Court

c) References to abstract norms formed by the Constitutional Court (e.g., the rules of procedure)

$3 / D$. Interpretation of the Constitution on the basis of the case law of ordinary courts

a) Interpretation referring to the practice of ordinary courts (not of single case decisions)

b) Interpretation referring to individual court decisions (as "precedents" in the judiciary)

c) Interpretation referring to abstract judicial norms (directives, principled rulings, law unification decisions, etc.)

3/E. Interpretation of constitutional provisions and fundamental rights on the basis of normative acts of other domestic state organs

4. External systemic and comparative law arguments:

4/A. Interpretation of fundamental rights on the basis of international treaties

$4 / B$. Interpretation of fundamental rights on the basis of individual case decisions or case law ('judicial' practice) of international fora.

4/C. Comparative law arguments: e.g., references to norms or case decisions of a particular foreign legal system

$4 / D$. Other external sources of interpretation (e.g., customary international law, ius cogens, etc.)

5. Teleological / objective teleological interpretation

6. Historical / subjective teleological interpretation (based on the intention of the

constitution-maker):

6/A. Interpretation based on ministerial / proposer justification

6/B. Interpretation based on draft material: references to travaux préparatoires / Materialen / and

legislative history

6/C. In general, references to the intention, will etc. of the constitution-maker

$6 / D$. Other reasons based on the circumstances of making or modifying/amending the constitution or the constitutional provision in question

7. Arguments based on jurisprudence / scholarly works

8. Interpretation in light of general legal principles

9. Substantive interpretation / non-legal arguments

Frequency (number): Number of decisions in which a method appears

Main types frequency: Number of decisions in which main methods appear through their sub-types

Weight (number): Total number of occurrences of a method within a decision

Weight (\%): Total number of occurrences of a method in \%

Main types weight (number and \%): Total number and \% of occurrences of main methods through their sub-types 